\title{
Fiscal Implications of the Federal Reserve's Balance Sheet Normalization*
}

\author{
Michele Cavallo, ${ }^{\mathrm{a}}$ Marco Del Negro, ${ }^{\mathrm{b}}$ W. Scott Frame, ${ }^{\mathrm{c}}$ \\ Jamie Grasing, ${ }^{a}$ Benjamin A. Malin, ${ }^{\mathrm{d}}$ and Carlo Rosa ${ }^{\mathrm{e}}$ \\ ${ }^{\text {a}}$ Federal Reserve Board \\ ${ }^{b}$ Federal Reserve Bank of New York \\ ${ }^{\mathrm{c}}$ Federal Reserve Bank of Dallas \\ ${ }^{\mathrm{d}}$ Federal Reserve Bank of Minneapolis \\ ${ }^{\mathrm{e}}$ Barclays
}

The paper surveys the recent literature on the fiscal implications of central bank balance sheets, with a special focus on political economy issues. It then presents the results of simulations that describe the effects of different scenarios for the Federal Reserve's longer-run balance sheet on its earnings remittances to the U.S. Treasury and, more broadly, on the government's overall fiscal position. We find that reducing longer-run reserve balances from $\$ 2.3$ trillion (roughly the amount when the Federal Reserve's balance sheet normalization program started) to $\$ 1$ trillion reduces the likelihood

${ }^{*}$ We thank Jim Clouse, Jane Ihrig, Deborah Leonard, Brian Madigan, and Larry Mize for helpful comments; Casey Clark, Erin Ferris, and Kimberly Zhakov for insightful conversations; and conference participants at the $2018 \mathrm{CEF}$ meeting in Milan for feedback. We are also grateful to the referee and the Co-Editor, Pierpaolo Benigno, for valuable suggestions. Sofia Baig, Chris Curfman, Khalela Francis, Gurubala Kotta, Margaret Sauer, and James Trevino provided excellent assistance. The views expressed herein are those of the authors and not necessarily those of their employers or any other entity within the Federal Reserve System. Author contact: Cavallo: Federal Reserve Board, 20th St. and Constitution Ave. NW, Washington, DC 20551 (e-mail: Michele.Cavallo@frb.gov); Del Negro: Federal Reserve Bank of New York, 33 Liberty St., New York, NY 10045 (e-mail: Marco.DelNegro@ny.frb.org); Frame: Federal Reserve Bank of Dallas, 2200 N. Pearl St., Dallas, TX 75201 (e-mail: Scott.Frame@dal.frb.org); Grasing: Federal Reserve Board, 20th St. and Constitution Ave. NW, Washington, DC 20551 (e-mail: Jamie.R.Grasing@frb.gov); Malin: Federal Reserve Bank of Minneapolis, 90 Hennepin Ave., Minneapolis, MN 55401 (e-mail: benjamin.malin@mpls.frb.org); Rosa: Barclays, 745 7th Ave., New York, NY 10019 (e-mail: carlorosa1@gmail.com). Carlo Rosa contributed to this paper while working at the Federal Reserve Bank of New York. 
of posting a quarterly net loss in the future from 30 percent to less than 5 percent. Further reducing longer-run reserve balances from $\$ 1$ trillion to pre-crisis levels has little effect on the likelihood of net losses.

JEL Codes: E58, E59, E69.

\section{Introduction}

In the aftermath of the global financial crisis and into the Great Recession, the U.S. Federal Reserve reduced its overnight interest rate to the effective lower bound and engaged in large-scale purchases of long-term U.S. Treasury and federal agency securities. From the start of 2008 through the end of 2014, the U.S. central bank's balance sheet grew from $\$ 900$ billion to $\$ 4.5$ trillion, with assets principally consisting of long-term U.S. Treasury notes and bonds ( $\$ 2.3$ trillion) and federal agency mortgage-backed securities (MBS) (\$1.8 trillion) 1

In 2017, the Federal Reserve's Federal Open Market Committee (FOMC) started implementing a "normalization program" to reduce the size of the central bank's balance sheet 2 However, important questions remain about the longer-run size and composition of the balance sheet. Portfolio choices can have important consequences for the level and variability of earnings remittances to the U.S. Treasury, both during and after the transition. Of course, the level and

\footnotetext{
${ }^{1}$ Data as of December 29, 2016. Federal Reserve balance sheet information is available weekly from Federal Reserve statistical release H.4.1, "Factors Affecting Reserve Balances," available at https://www.federalreserve.gov/releases/h41/.

${ }^{2}$ The revised version of this paper was submitted to the journal in November 2018. Hence, part of the narrative and the simulations herein reflect the plans and the policies that were in place at that time, namely, the FOMC's June 2017 Addendum to the Policy Normalization Principles and Plans (https://www.federalreserve.gov/newsevents/pressreleases/monetary20170614c. htm) and the decision to implement this program starting in October 2017. The simulations do not incorporate those policy announcements and decisions that have occurred thereafter. Most notably, these include the Balance Sheet Normalization Principles and Plans announced at the conclusion of the March 2019 FOMC meeting, the end of the reduction in the size of the Federal Reserve's securities holdings that was decided at the July 2019 FOMC meeting, and the plan to purchase Treasury bills into 2020:Q2 to ensure that the supply of reserves remains ample over time, which was announced on October 11, 2019.
} 
volatility of remittances are not factors influencing monetary policy decisions, which are made to achieve the central bank's statutory goals of maximum employment and stable prices. Nonetheless, the central bank may have to deal with political economy concerns during the transition related to the volatility of remittances to the Treasury, including the possibility of experiencing net losses 3

In this paper, we simulate the transition of the Federal Reserve's balance sheet to four alternative longer-run sizes in an effort to understand the implications for both remittances and broader fiscal outcomes. To do so, we combine two models maintained by the Federal Reserve Board: (i) the System Open Market Account (SOMA) model (Carpenter et al. 2015), which, for a given interest rate scenario, generates detailed projections of the evolution of the balance sheet and associated net income; and (ii) a large-scale macroeconomic model (FRB/US), which generates (among other things) future paths for interest rates as well as government revenues, expenditures, and debt. Importantly, this approach allows for general equilibrium effects as changes to the central bank's balance sheet provide (or remove) monetary accommodation, which alters interest rate paths that are important determinants of remittances and broader economic activity 4 The results of our simulations suggest three broad takeaways.

First, the level of longer-run reserve balances affects the probability that the Federal Reserve faces net losses at some point in

\footnotetext{
${ }^{3}$ As will be discussed in section 2.2, if the Federal Reserve's earnings are insufficient to cover operational costs, dividend payments, and any amount needed to maintain a surplus, remittances to the Treasury are suspended and a deferred asset is recorded. This debit balance would represent the amount of future net earnings the Federal Reserve will need to realize before remittances to the Treasury resume.

${ }^{4}$ Empirical studies have found that a larger balance sheet provides substantial accommodation when short-term interest rates are constrained by the effective lower bound (e.g., D'Amico et al. 2012; Gagnon et al. 2011). Away from the lower bound, the central bank can, in theory, keep the amount of monetary accommodation unchanged by moving short-term rates to offset the effects of the change in its balance sheet. As a result, any model of the fiscal implications of central bank balance sheet policy must also take a stand on interest rate policy. In our analysis below using the FRB/US model, short-term interest rates are assumed to follow an inertial Taylor (1999) rule.
} 
the future. If long-run reserve balances were to remain near the level when the balance sheet normalization program was announced (around $\$ 2.3$ trillion), the probability of realizing net losses at some point is around 30 percent 5 In the context of the macroeconomic model, this arises for two reasons: (i) new assets purchased to maintain the elevated level of reserve balances are associated with negative expected future net income due to negative Treasury term premiums; and (ii) net income generated from legacy assets declines as interest expenses increase (as short-term interest rates rise per the monetary policy rule), while interest income is unchanged. Of course, as of October 2017, the FOMC started implementing a balance sheet normalization program that aims at bringing the magnitude of reserve balances to a significantly lower level over time. In light of this development, we also consider three scenarios with lower longer-run levels of reserve balances. We find that, in contrast to the $\$ 2.3$ trillion scenario, shrinking reserve balances to a longerrun level of $\$ 1.0$ trillion reduces the likelihood of net losses to less than 5 percent. In addition to not buying new assets while term premiums are negative, the smaller balance sheet provides less monetary accommodation, which implies that short-term interest rates increase less rapidly. Further reducing longer-run reserve balances from $\$ 1$ trillion to pre-crisis levels has little effect on the likelihood of net losses.

Second, the possibility that the Federal Reserve would not be able to cover any losses with future seigniorage under current monetary policy - what Del Negro and Sims (2015) refer to as "central bank insolvency" - is truly negligible (i.e., less than 0.02 percent).

Finally, the overall fiscal effect - as measured by the ratio of federal debt to gross domestic product (GDP) at the end of our forecast horizon - of a larger longer-run level of reserve balances is positive (that is, the debt-to-GDP ratio is smaller). However, the magnitude depends on the monetary policy rule assumed to govern shortterm interest rates. An important caveat to our results, especially in

${ }^{5} \mathrm{As}$ is further explained at the beginning of section 3 , this scenario is neither consistent with the current FOMC's balance sheet program nor an indication of any potential future Federal Reserve policy. We present this counterfactual, illustrative scenario only to understand the fiscal implications that could have arisen if reserve balances remained close to that level. 
terms of the overall fiscal effect, is that they depend on assumptions embedded in the FRB/US model 6

Our analysis is related to an emerging literature that projects central bank remittance flows under different portfolio normalization principles. Some research approaches this from an accounting and finance perspective and uses very detailed information about central bank securities holdings, coupled with simulated interest rate path(s), to estimate future remittances (e.g., Carpenter et al. 2015; Christensen, Lopez, and Rudebusch 2015). Macroeconomic analysis using simple quantitative models has also been conducted (e.g., Del Negro and Sims 2015; Hall and Reis 2015). Most of these papers suggest that the likelihood of the Federal Reserve recording losses (and temporarily ceasing remittances) is small.

Our contribution to this literature is twofold. First, we provide a broad discussion of both the institutional and the conceptual issues surrounding fiscal implications of central bank balance sheets, with a focus on the Federal Reserve. This survey strives to connect different strands of the literature related to central bank balance sheets, including macroeconomics, finance, and political economy. We also relate the more recent (post-financial crisis) contributions to an earlier literature that mainly focused on emerging economies (e.g., Stella 1997). The second contribution relates to our simulations. This is the first study about the fiscal implications of different longer-run central bank balance sheet sizes. Unlike other papers, we analyze the fiscal implications of balance sheet choices in a broad sense, in that we consider not only the implications for remittances but also the effects on the government's overall fiscal position.

\footnotetext{
${ }^{6}$ Expectations in the FRB/US model are not "rational" in the sense of being fully consistent with the equilibrium of the model. This feature has important implications for our results. For instance, in standard rational expectations DSGE (dynamic stochastic general equilibrium) models, Wallace's (1981) irrelevance result holds, implying that the central bank's balance sheet operations have no effect on equilibrium outcomes due to Ricardian equivalence. In the FRB/US model, it is assumed that (i) the acquisition of long-term government bonds by the central bank lowers the term premium; and (ii) doing so stimulates economic activity. In FRB/US, both channels are modeled in a reduced-form way. The reader should bear in mind that our results are dependent on the specification of these relationships.
} 
The paper is organized as follows. Section 2 provides a broad overview of the various mechanisms by which the Federal Reserve's balance sheet has fiscal implications. Here, we consider both a consolidated government budget perspective and a more narrow view that acknowledges that the central bank is an independent agency that produces an observable flow of remittances to the fiscal authority. Section 3 presents the results of our analysis of the fiscal implications of the Federal Reserve's balance sheet based on macroeconomic simulations using the SOMA and FRB/US models. Section 4 offers some concluding thoughts.

\section{Central Bank Balance Sheets: Fiscal Implications and Political Economy Considerations}

Monetary policy always has significant fiscal implications. In addition to influencing the interest rates at which the federal government finances its debt, monetary policy also affects broader economic activity (with implications for tax revenues and expenditures) and inflation (thus affecting the real cost of debt financing). Changes in the size and composition of the central bank's balance sheet have additional fiscal consequences. Below, we begin by discussing these implications from the consolidated government budget perspective, which, in the U.S. case, simply means adding the Federal Reserve's assets and liabilities to those of the federal government 7 This is the perspective that is generally considered in macroeconomic models and is a useful starting point for our discussion. However, a consolidated government budget perspective ignores the fact that the fiscal authority and the central bank are different institutions, each with its own budget constraint. We therefore relax the assumption of a consolidated government budget in subsequent subsections.

Before proceeding, it is helpful to clarify a couple of issues. First, the Federal Reserve's prospective asset choices are constrained by law and-for practical purposes - are limited to

\footnotetext{
${ }^{7}$ This implies subtracting the Federal Reserve's holdings of U.S. Treasury debt from the Treasury's liabilities, as they cancel each other out in the consolidated government's balance sheet.
} 
acquiring U.S. Treasury and federal agency securities 8 Federal agency securities include debt and MBS issued by congressionally chartered government-sponsored enterprises (GSEs): Fannie Mae, Freddie Mac, the Federal Home Loan Bank System, the Farm Credit System, and Farmer Mac. Collectively, the MBS guaranteed by Ginnie Mae, Fannie Mae, and Freddie Mac are referred to as "agency MBS." Each GSE benefits from strong investor perceptions of an implied federal guarantee of their debt obligations due to various charter provisions and past government actions (e.g., Frame and White 2005; Frame et al. 2015) 9 Second, observed long-term Treasury bond yields can be decomposed conceptually into expectations about the future path of nominal short-term interest rates and term premiums that principally reflect compensation required by investors related to uncertainty about this expected path (e.g., Adrian, Crump, and Moench 2013; Kim and Wright 2005). Estimated term premiums are typically positive and increasing in bond maturity, although they have been negative at times.

\subsection{A Consolidated Government Budget Perspective}

We start our discussion by considering the simple case in which the Federal Reserve's balance sheet is primarily funded by currency, as was true before the Great Recession. Here, the only portfolio choice for the central bank relates to its asset composition. For many years, the Federal Reserve purchased only U.S. Treasury securities, thus further narrowing its portfolio choice to the duration of its asset portfolio 10 From a consolidated balance sheet perspective, the Federal Reserve's holdings of U.S. Treasury debt implies that these securities effectively "cancel out." Currency, which bears zero interest, then becomes a liability of the consolidated government. As long

\footnotetext{
${ }^{8}$ The Federal Reserve is also authorized to purchase and hold short-term municipal debt, bankers' acceptances, and foreign sovereign debt.

${ }^{9}$ Nevertheless, by law, GSEs are required to clearly state that there is no guarantee. The exception is for Ginnie Mae MBS, which do carry a full-faithand-credit guarantee from the U.S. government. Ginnie Mae is considered a "government corporation" rather than a GSE.

${ }^{10}$ For a history and explanation of the Federal Reserve's portfolio, see "Alternative Instruments for Open Market and Discount Window Operations," available at https://www.federalreserve.gov/boarddocs/surveys/soma/alt_instrmnts.pdf.
} 
as interest rates are positive, this activity lowers funding costs for the consolidated government 11

We next consider the fiscal implications of a balance sheet expansion that involves purchases of Treasury securities financed by increasing reserves rather than by increasing currency in circulation. From a consolidated budget perspective, Federal Reserve purchases of these securities are analogous to the Treasury replacing them with overnight debt, thereby shortening the duration of overall government liabilities. The implications for the consolidated government's funding costs depend on the duration of the securities being purchased by the Federal Reserve. If the term premium is positive, a larger central bank balance sheet should lower government funding costs (on average, over the long run) as the government collectively pays lower term premiums. However, expanding the balance sheet using interest-bearing liabilities does increase the interest rate risk associated with the consolidated government balance sheet. In other words, since the government has to refinance its debt at an uncertain future interest rate, this implies a higher expected volatility of funding costs. See Greenwood, Hanson, and Stein (2015) for a thorough discussion of these tradeoffs.

In the case in which the Federal Reserve acquires non-Treasury securities financed by increasing reserves, it expands both the assets and liabilities of the consolidated government balance sheet. Assuming that the yield on acquired securities carries a premium relative to Treasury securities, the effect on the consolidated government's net revenues will be positive on average. Importantly, purchases of nonTreasury securities imply that the consolidated government is taking on additional risk. For instance, all non-Treasury assets involve some credit risk, or the risk of principal loss arising from a counterparty failing to make required payments 12 In the case of agency MBS, the government faces prepayment risk, as changes in interest rates shift underlying cash flows forward or backward in time.

\footnotetext{
${ }^{11}$ If the monetary authority pursues an interest rate policy, currency demand is determined by the private sector (see the discussion in Del Negro and Sims 2015).

${ }^{12}$ In practice, however, the purchase of federal agency securities issued by Fannie Mae and Freddie Mac effectively carries no credit risk while the two institutions remain in federal conservatorship.
} 
So far, we have discussed the fiscal implications stemming from how changes in the size and composition of the Federal Reserve's balance sheet affect the assets, liabilities, and associated net income of the consolidated government in partial equilibrium. But central bank balance sheet policies can also have general equilibrium effects by changing the prices of assets, goods, and services, which ultimately affects the pace of economic activity 13 To the extent that balance sheet policies provide more accommodation, they will be associated with temporarily faster economic growth, which in turn increases tax revenues (e.g., due to higher income and capital gains), reduces government expenditures (e.g., lower unemployment benefits), and thus improves the path of the debt-to-GDP ratio (e.g., Rosengren 2013). Moreover, they will put upward pressure on inflation, thus decreasing the real value of the debt. Thus, asset purchase programs can (i) change the value of outstanding government obligations and (ii) have fiscal implications beyond altering the funding costs of government debt. As we will see in our simulations below, such general equilibrium effects can be quantitatively important.

The fiscal authority may also respond to the central bank's actions, due to its differing objectives. In the U.S. case, the Federal Reserve is charged with achieving a dual mandate of maximum employment and stable prices, while the Treasury is principally concerned with minimizing debt service costs and fiscal risk. These differing goals may be inconsistent in some circumstances. For example, if Federal Reserve asset purchases lower term premiums, the Treasury may decide that it is in taxpayers' interest to issue longer-term debt. Such an action could result in upward pressure on term premiums and potentially offset the central bank's policy easing. One way to deal with this problem is to have formal coordination between the central bank and fiscal authorities. A prominent international example of this comes from the United Kingdom. As explained by Greenwood et al. (2014), that nation's Debt Management Office is

\footnotetext{
${ }^{13}$ This is particularly relevant when short-term interest rates are constrained by the effective zero lower bound, as in the aftermath of the Great Recession. In order to have general equilibrium effects at all, one has to break Wallace's (1981) irrelevance result. As discussed in the introduction, this is done in the FRB/US model by assuming that balance sheet policy affects the term premium embedded in longer-term government yields.
} 
mandated to "ensure that debt management is consistent with aims of monetary policy."

There is evidence that this tension between the objectives of central banks and fiscal authorities can be important. Greenwood et al. (2014) suggest that this was the case for the United States in the aftermath of the Great Recession, when the Federal Reserve purchased long-term Treasury bonds as part of its quantitative easing, while the Treasury issued more long-term debt to fulfill its goal of minimizing the present value of financing costs. The authors estimate that the Treasury's active maturity extension program offset 35 percent of the maturity-shortening effect of asset purchases 14 Other researchers have suggested that the lack of coordination in Japan during the late 1990s and early 2000s might have jeopardized that nation's economic recovery and, more importantly, left monetary policymakers with a credibility issue, as the public was unconvinced they could commit to future expansions (e.g., Ito and Mishkin 2006; Kuttner and Posen 2001; and references therein).

\subsection{Central Bank Remittances and the Central Bank's Intertemporal Budget Constraint}

The consolidated government budget view of central banking made in many macroeconomic models arises out of convenience. However, the Federal Reserve is an independent agency that maintains its own balance sheet and income statement, which generates an observable flow of remittances to the Treasury. By law, the Federal Reserve must distribute its earnings to the Treasury, net of operating expenses and dividends and allowing for a retained surplus of no more than $\$ 6.825$ billion 15 In the event that earnings are insufficient to cover these costs, then no remittances occur, and a "deferred asset" is

\footnotetext{
${ }^{14}$ Swanson (2011) describes a similar tension during "Operation Twist" of 1961.

${ }^{15}$ Section 7 of the Federal Reserve Act defines the "division of earnings." These earnings principally reflect the difference between interest earned on assets and that paid on liabilities. Assets consist almost entirely of marketable securities that pay coupon interest - principally U.S. Treasury notes and bonds and agency MBS. Liabilities are primarily Federal Reserve notes in circulation, bank reserves, the Treasury General Account (TGA), the foreign repo (repurchase agreement) pool, and reverse repurchase agreements. Notes in circulation and the balance on the TGA pay no interest, while reserves and repurchase agreements incur interest expenses.
} 
booked as a negative liability on the balance sheet 16 Carpenter et al. (2015) provide a detailed overview of the Federal Reserve's balance sheet and income statement mechanics.

Separating the central bank and federal government budget constraints naturally raises questions about the determinants of central bank remittances, the probability of recording net losses, and central bank solvency. These questions had largely been ignored by much of the macroeconomic literature on advanced economies, mainly because, for the Federal Reserve, (i) liabilities consisted almost exclusively of currency, and (ii) assets consisted almost exclusively of government securities with relatively short maturity (e.g., Bukhari, Cambron, Fleming et al. 2013). These two conditions implied that central bank income and remittances to the fiscal authority always remained positive, although they did vary substantially over the postwar period (e.g., Bukhari, Cambron, Del Negro et al. 2013). The recent financial crisis - and the central bank balance sheet expansions that followed - raised academic interest in central bank balance sheets 17 We should stress that for emerging market central banks, balance sheet concerns have long been a topic of policy discussion. This was both because (i) assets were often denominated in foreign currency, whose value was volatile when measured in local currency, and (ii) local banking crises often resulted in non-performing loans being moved to the central bank balance sheet. While the remainder of this section focuses on the Federal Reserve - since it aims to provide a framework for understanding the simulation results below-some lessons also apply to other central banks.

\subsubsection{Central Bank Remittances}

The average size and variability of Federal Reserve remittances to the Treasury depend on some factors controlled by the central bank,

\footnotetext{
${ }^{16}$ For an accounting definition of a deferred asset, see paragraph 11.96 of the Financial Accounting Manual for Federal Reserve Banks, available at https://www.federalreserve.gov/aboutthefed/financial-accounting-manual.htm.

${ }^{17} \mathrm{~A}$ non-exhaustive and ever-expanding list of recent papers includes Bassetto and Messer (2013); Benigno (2019); Benigno and Nisticò (2019); Carpenter et al. (2015); Christensen, Lopez, and Rudebusch (2015); Del Negro and Sims (2015); Greenlaw et al. (2013); and Hall and Reis (2015).
} 
including the size and composition of its balance sheet and asset sales.

The effect of increasing the size of the Federal Reserve's balance sheet on remittances depends on the types and maturities of the purchased assets. The base case would be the purchase of Treasury securities. As long as the term premium is positive and increasing with duration, a longer-duration portfolio implies a higher net interest margin and, hence, higher average net income and remittances over time. However, to the extent that marginal assets are funded by issuing short-term interest-bearing liabilities (i.e., reserves and reverse repurchase agreements), acquiring longer-duration assets implies some risk associated with uncertain future interest expenses. As a result, the volatility of remittances will generally increase with the duration of the purchased assets.

Since the start of the Federal Reserve's quantitative easing program, the central bank purchased (and still holds) a large share of agency MBS guaranteed by Fannie Mae, Freddie Mac, and Ginnie Mae. During 2008:Q4 and 2009:Q1, the Federal Reserve also purchased agency debt securities, which behave similar to Treasury securities, but with marginally higher yield spreads and volatility owing to liquidity risk premiums. Agency MBS have significantly higher coupons than Treasury securities due to the presence of embedded borrower prepayment options that make the timing of cash flows uncertain. Hence, larger holdings of agency MBS result in higher average remittances and greater remittance volatility over time. Finally, selling assets generally results in gains or losses that are immediately recognized in income and therefore generally increase the variability of remittances 18

Existing research has generally painted a benign picture of the Federal Reserve's net income in future years under baseline projections for the evolution of the balance sheet (e.g., Carpenter et al. 2015; Christensen, Lopez, and Rudebusch 2015; Ferris, Kim, and Schlusche 2017; Greenlaw et al. 2013; and Hall and Reis 2015) and suggests that the likelihood of recording a sizable

\footnotetext{
${ }^{18}$ However, in principle, asset sales could be structured in such a way as to smooth remittances, recognizing capital gains in periods when income would otherwise be low and vice versa.
} 
and long-lasting deferred asset is quite small. Section 3.2 presents our own simulations of Federal Reserve income using the FRB/US model under various scenarios for the future size of the balance sheet.

\subsubsection{The Central Bank's Intertemporal Budget Constraint}

Net losses and temporary negative levels of capital are not an impediment to normal central bank functioning per se, as the Federal Reserve would simply record a deferred asset. However, in principle, the deferred asset could become so large that it could not be expected to be covered by future earnings. In this extreme case, either the Treasury would inject resources into the central bank so that it could continue to pursue its policy stance or the central bank would need to adjust monetary policy in order to meet its obligations. Del Negro and Sims (2015) refer to this situation as "central bank insolvency," and we will continue to use this term in the remainder of the paper as a shorthand. However, it should be understood that the term "insolvency" does not have the same meaning as for a private issuer of liabilities. This is because a central bank is never forced to default in a fiat money regime, and so its liabilities remain risk free in nominal terms.

A few recent papers discuss the central bank's intertemporal budget constraint (e.g., Bassetto and Messer 2013; Benigno and Nisticò 2014; Del Negro and Sims 2015; and Hall and Reis 2015). This literature shows that a central bank is "solvent" (in the sense discussed above) if the sum of its "tangible wealth" (the difference between the current market value of assets and interest-bearing liabilities) plus "intangible wealth" (the expected present discounted valueEPDV - of future seigniorage) is positive. The sum of the twotangible and intangible wealth - equals the EPDV of remittances. If the central bank posts losses but intangible wealth is positive and larger, the institution should not require recapitalization from the fiscal authority in order to pursue its mandate, as it can compensate current losses by borrowing against future remittances. However, if the EPDV of remittances were negative, the central bank would be "insolvent." Of course, a central bank in a fiat money regime can always address this situation by creating more liabilities and/or 
"printing money" (that is, generating more seigniorage), but at the cost of potentially compromising its inflation objective 19

The intertemporal budget constraint perspective offers a few important implications. First, a central bank without interestbearing liabilities cannot be insolvent as long as interest income exceeds operating expenses. Second, factors that affect the variability of remittances, such as the choice to hold assets to maturity or use market-value accounting, may be less relevant from an intertemporal perspective than one may initially think. Recognizing losses at once, or delaying the recognition until maturity, makes little difference for the present-value calculations.

Finally, the correlation between the value of tangible and intangible wealth is key to understanding whether solvency is at stake for a given adverse scenario. For instance, if scenarios in which the value of assets falls are also scenarios in which the EPDV of future seigniorage increases, then intangible wealth provides a hedge for the central bank's tangible wealth. Inflationary scenarios are generally examples in which such a hedge is in effect, as seigniorage generally increases with inflation. Del Negro and Sims (2015) and Reis (2016) emphasize the quantitative importance of the EPDV of seigniorage for assessing central bank solvency and find that it is potentially quite large for the Federal Reserve - possibly well above the current value of interest-bearing liabilities. However, uncertainty about future currency demand makes these present-value calculations tentative.

\subsection{Political Economy Considerations}

Despite the extremely remote possibility of Federal Reserve insolvency, maintaining a large balance sheet could potentially lead to political pressure on the central bank for at least two reasons.

First, as discussed above, a large central bank balance sheet increases the likelihood of reporting a net loss, which would result in

\footnotetext{
19 "Printing money" should be understood in a broad sense, including keeping the interest rate on excess reserves (IOER) lower than needed to control inflation. Del Negro and Sims (2015), Hall and Reis (2015), Reis (2013), Sims (2005), and Stella (2005) all elaborate in different ways as to why an inflation-targeting central bank is subject to an intertemporal budget constraint, even in a fiat money regime.
} 
zero remittances to the Treasury for some time. While a large balance sheet may reduce the consolidated government funding costs on average, it can also be disadvantageous for public finances under some circumstances (e.g., when interest rates increase unexpectedly). Since Federal Reserve income statements are observable to the public, reporting a net loss lays bare such circumstances and places the central bank's policies in the spotlight.

Second, large amounts of excess reserves imply substantial interest payments to the banking sector. From the consolidated budget perspective - and to the extent that excess reserves have been issued to purchase Treasury securities - these payments simply reflect the need to finance federal debt 20 Put differently, a central bank's decision to raise interest rates always makes funding public debt more expensive, at least initially, regardless of the size of its balance sheet and of the holders of public liabilities. Nonetheless, large payments to the banking system could result in political pressure against maintaining or raising the interest rate paid on excess reserves (IOER).

Experience from other central banks - especially those in emerging markets - suggests that political economy concerns can influence a central bank's monetary policy goals, particularly under circumstances in which the mandate of the central bank is of a different nature from that of the Federal Reserve 21 Stella (1997, 2005) notes that several central banks have suffered sizable losses that eventually interfered with the effective conduct of monetary policy 22 Relatedly, Cukierman $(2008,2011)$ argues that when central bank capital becomes negative and drops below some threshold, there is a danger that the political establishment might prevent the central bank from following useful policies that could nonetheless lead to additional losses. This literature suggests that a large balance sheet, and

\footnotetext{
${ }^{20}$ However, this is not the case when financing non-Treasury assets, such as agency MBS.

${ }^{21}$ Consistent with political sensitivity, recent cross-country research identifies a discontinuity in the central bank profit distribution skewed away from losses. See Goncharov, Ioannidou, and Schmalz (2017).

${ }^{22}$ Dziobek and Dalton (2005), Klüh and Stella (2008), Leone (1993), and Stella (1997, 2005, 2009) provide brief case studies. Klüh and Stella (2008) argue that central bank losses can result in a negative public perception of the institution and its leadership.
} 
the associated increased risk of incurring losses, can endanger central bank independence. That said, many of the countries considered in these studies are emerging economies with arguably weaker institutions than those in the United States, so it is not clear to what extent their experiences apply to the Federal Reserve 23 Moreover, even among emerging markets, central bank balance sheet problems have not always led to poor monetary policy performance. For instance, Chile was able to pursue successful monetary policy for several years with negative capital, partly because the fiscal authority was supportive of the central bank's mandate. Moreover, as discussed by Eichengreen (2015), the Czech and the Israeli central banks have also operated with negative capital for extended periods without damaging their policies.

The experience of advanced economies such as Japan and Switzerland also suggests that political economy considerations may, at times, pose constraints on central bank policy. In particular, Stella (2005, p. 338) argues that "in early 2002 the market raised questions as to the likely duration of the Bank of Japan's willingness to use its rinban operations to influence the long end of the government bond yield curve, as an eventual rise in interest rates would subject it to losses that could exhaust its capital and reserves."24 The recent abandonment of the minimum exchange rate policy by the Swiss National Bank (SNB) is further evidence that balance sheet concerns can take center stage in policy discussions. In the SNB's own words: "Had the SNB delayed the discontinuation of the minimum exchange rate, this would only have been at the expense of an uncontrollable expansion of the SNB balance sheet by hundreds of billions of Swiss francs, and potentially by several times Swiss GDP. Such an expansion would have severely impaired the SNB's future ability to conduct monetary policy and jeopardized the fulfillment of its mandate in the long term. Moreover, given the fact that the minimum exchange rate was no longer sustainable, further intervention would have been pointless, and the enormous losses arising from it

\footnotetext{
${ }^{23}$ Many of the central bank balance sheet problems discussed in the literature arose because the government had forced the central bank to bail out banks following financial crises.

${ }^{24}$ Similar concerns about possible future losses have been raised in regard to the Bank of Japan's latest balance sheet expansion (see Fujiki and Tomura 2017).
} 
could not have been justified" (Swiss National Bank 2015). Amador et al. (2016) provide an insightful analysis of the Swiss central bank's decision in light of its balance sheet constraints.

To address the political economy risks associated with losses, a central bank may take a range of actions. First, the central bank can provision for future losses by increasing its surplus capital in order to use it as a buffer against adverse shocks 25 Cukierman (2008, 2011), Goodfriend (2014a, 2014b), and Stella (2005) all advocate such an approach. However, increasing the size of surplus capital is not a feasible option for the Federal Reserve, as current law limits this surplus to $\$ 6.825$ billion 26 Another clear limitation of this approach is that the fiscal authority may be tempted to appropriate some of this capital, as happened to the Federal Reserve in 1993, 2005, 2015, and 2018. Second, the central bank could make an ex ante agreement with the fiscal authority to absorb central bank losses, as is the case in the United Kingdom (e.g., McLaren and Smith 2013). While such an agreement may seem desirable, it may also come with limits on the central bank's ability to pursue independent monetary policy (e.g., in the United Kingdom, some balance sheet actions need approval by the Treasury). Finally, the central bank could reduce its interest-bearing liabilities (and increase the EPDV of seigniorage) by increasing required reserves and not paying interest on them. However, such an action amounts to a forced transfer of resources

\footnotetext{
${ }^{25}$ Stella (2005) observes that countries with large foreign exchange exposure on their balance sheet tend to have mechanisms to smooth the effect of exchange rate movements on their accounts. This suggests that the small size of central bank capital that is characteristic of many advanced economies could be a legacy of a period in which these institutions did not actively use their balance sheet for monetary policy purposes.

${ }^{26}$ At the time we ran the simulations presented in section 3 , the statutory limit on aggregate Federal Reserve surplus capital was $\$ 10$ billion, which is the value that we assumed in our scenarios. The limit on Federal Reserve surplus capital has been reduced to $\$ 6.825$ billion as a result of the Bipartisan Budget Act of 2018 and the Economic Growth, Regulatory Relief, and Consumer Protection Act of 2018. For the accounting definition of Federal Reserve surplus, see paragraph 12.10 of the Financial Accounting Manual for Federal Reserve Banks, available at https://www.federalreserve.gov/aboutthefed/financial-accounting-manual.htm. For more details about changes to the statutory limit on aggregate Reserve Bank surplus, see the 2018 Audited Annual Financial Statements of the Federal Reserve System (in particular, Notes to Combined Financial Statements, p. 15) available at https://www.federalreserve.gov/aboutthefed/files/combinedfinstmt2018.pdf.
} 
from the banking system to the central bank - a policy change that could generate significant political opposition.

\subsection{The Central Bank Balance Sheet and Monetary Policy Decisionmaking}

As we just discussed, political economy considerations can pose constraints on monetary policy insofar as they create incentives for central bankers to limit remittance volatility, avoid losses, and ultimately eliminate the possibility of being forced to ask for recapitalization from the fiscal authority 27 Constraints can lead to suboptimal outcomes, and recent research has sought to incorporate such constraints into formal models. Benigno and Nisticò (2019) study optimal conventional monetary policy, taking into account the central bank's desire to avoid declines in net worth and the potential need for recapitalization. They find that such constraints can introduce an inflationary bias, as the central bank relies on seigniorage to shield itself from losses (since higher inflation entails an increase in the EPDV of seigniorage). Other work by Del Negro and Sims (2015) shows that - in some circumstances - a large central bank balance sheet can lead to a self-fulfilling balance sheet crisis. A sudden increase in expected inflation would cause the value of the longduration assets held by the central bank to plummet, calling into question the solvency of the central bank. If the latter cannot count on backing from the fiscal authority, it can only restore solvency by generating more seigniorage, thereby validating the inflationary expectations. However, using a simple quantitative model calibrated on U.S. data, Del Negro and Sims (2015) also find that under the current size of the central bank balance sheet, such a self-fulfilling crisis is extremely unlikely.

Another strand of literature suggests that balance sheet constraints can be turned to the central bank's advantage in situations in which additional obstacles are in place, such as the zero lower

\footnotetext{
${ }^{27}$ For the case of the United States, the level and volatility of remittances do not prevent the FOMC from conducting monetary policy in conformity with its mandate and are thus not the focus of monetary policy decisions. As also noted by Carpenter et al. (2015), foreign central banks, such as the Czech National Bank, have operated with a negative equity position and zero remittances.
} 
bound (ZLB) on nominal interest rates. This is the "signaling theory of QE" (Bauer and Rudebusch 2014; Berriel and Mendes 2015; Bhattarai, Eggertsson, and Gafarov 2015), according to which the central bank, when constrained by the ZLB, engages in quantitative easing in order to signal to markets its intention to keep interest rates low for a long time. It is well understood that monetary policy faces a so-called time-inconsistency problem in a liquidity trap: it would like to promise low future rates in order to stimulate inflation and economic activity, but such promises may not be credible, as they may conflict with future policymaker objectives. Acquiring long-term assets and funding them with short-term interest-bearing reserves imply that the central bank would face net losses if it were to raise interest rates too fast. Hence, the constraint imposed by a large balance sheet helps in addressing the time-inconsistency problem because constrained policymakers are forced to stick to their promises. Finally, in a provocative paper, Benigno (2019) turns the central bank solvency concern on its head and argues that the central bank's intertemporal budget constraint can actually become a pillar of price stability. The intuition for this result closely follows the ideas behind the fiscal theory of the price level (see Sims 2013 for a recent description), according to which the present value of government surplus pins down the real value of government debt and therefore the price level for a given amount of existing nominal debt. Similarly, Benigno (2019) argues that a central bank with positive nominal assets can rule out hyperinflations or deflations by committing to a given stream of remittances to the fiscal authority, expressed in real terms.

\section{Simulations}

This section presents the results of simulations run using the Federal Reserve Board's SOMA and FRB/US models in an effort to quantify the fiscal implications of different longer-run configurations of the Federal Reserve's balance sheet 28 Specifically, we consider

\footnotetext{
${ }^{28}$ The FRB/US model is a large-scale estimated general equilibrium model of the U.S. economy that has been in use at the Federal Reserve Board since 1996. Further information is available at https://www.federalreserve.gov/econres/usmodels-about.htm The SOMA model (Carpenter et al. 2015) generates detailed
} 
four illustrative scenarios corresponding to different longer-run levels of central bank reserve balances: $\$ 100$ billion, which is intended to represent a return to a pre-crisis "scarce-reserves" balance sheet; $\$ 2.3$ trillion, which roughly corresponds to the level of reserves as of March 31, 2017; and two levels in between, namely, $\$ 500$ billion and $\$ 1$ trillion 29 The $\$ 2.3$ trillion longer-run reserve balance scenario implies that reserves would have remained elevated. We stress that this scenario is neither consistent with the current FOMC's balance sheet program nor any indication of future Federal Reserve policy. We present this counterfactual scenario only to understand the fiscal implications that could have potentially arisen if reserve balances were not reduced through balance sheet normalization. The other scenarios, which feature a gradual reduction in securities holdings through the medium term, are in line with the FOMC's balance sheet normalization program announced at the conclusion of the June 2017 FOMC meeting 30

\subsection{Model Setup}

Our simulations, which begin as of 2017:Q1 and run through 2035:Q4, require assumptions about the configuration of the Federal Reserve's balance sheet and projected paths for financial and macroeconomic variables that affect the evolution of the balance sheet and related income 31 Importantly, all assumptions are based on publicly available sources, including the FOMC's Policy Normalization Principles and Plans as amended by the FOMC's June 2017

projections of the evolution of the Federal Reserve balance sheet and associated net income, conditional on interest rate paths projected by FRB/US.

${ }^{29}$ The projections in the 2016 SOMA Annual Report for Domestic Open Market Operations consider a baseline scenario with a longer-run level of reserve balances of $\$ 500$ billion and two alternative scenarios with longer-run reserve balances of $\$ 100$ billion and $\$ 1$ trillion. See https://www.newyorkfed.org/medialibrary/ media/markets/omo/omo2016-pdf.pdf

${ }^{30}$ As explained earlier in footnote 2 , because the revised version of this paper was submitted to the journal in November 2018, the simulations stemming from these other three scenarios do not reflect the policy announcements and decisions that have occurred in March, July, and October 2019.

${ }^{31} \mathrm{We}$ also assume that the fiscal authority does not respond to the size of the Federal Reserve's balance sheet - either in terms of its willingness to engage in deficit spending or in terms of its debt-management strategy. 
addendum, survey-based expectations for policy and financial variables prepared by the Federal Reserve Bank of New York's Markets Group, and the March 2017 public version of the FRB/US model. We highlight a few features that are important for understanding our results below. Appendix 1 describes all model inputs in greater detail.

Our starting point is the configuration of the Federal Reserve's balance sheet at the end of 2017:Q1. On the asset side, we assume that (i) securities are never sold and (ii) proceeds from principal payments on securities held in the SOMA portfolio prior to January 2018 are fully reinvested 32 Specifically, maturing Treasury securities are assumed to be rolled over, and principal payments from holdings of agency debt and agency MBS are assumed to be reinvested in agency MBS 33 We also assume that starting in January 2018, reinvestments of principal payments received from SOMA securities holdings are phased out according to the balance sheet normalization program described in the FOMC's June 2017 Addendum to the Policy Normalization Principles and Plans. Specifically, such payments are assumed to be reinvested only to the extent that they exceed gradually rising caps 34 Finally, we assume that no additional asset purchases are made until reserve balances reach their longer-run level, at which point purchases of Treasury securities resume to keep up with currency and capital growth and to offset the runoff of agency $\mathrm{MBS}$ as they continue to pay down 35 In

\footnotetext{
${ }^{32}$ The second assumption is in line with expectations drawn from the June 2017 Federal Reserve Bank of New York's Survey of Primary Dealers and Survey of Market Participants (see https://www.newyorkfed.org/ markets/primarydealer_survey_questions.html and https://www.newyorkfed. org/markets/survey_market_participants.html). But this is not consistent with realized FOMC policy, as full reinvestments ceased in October 2017. In section 3.2 .5 , we present updated simulations, which account for the evolution of the balance sheet through June 2018.

${ }^{33}$ While the maturity dates for Treasury securities and agency debt are known with certainty, the timing of the principal paydowns on agency MBS is uncertain and is a function of interest rates and economic conditions. For the latter, see Carpenter et al. (2015, pp. 260-61) and Bonis, Kandrac, and Pardue (2017) for a discussion of the factors affecting prepayments of agency MBS.

${ }^{34}$ See https://www.federalreserve.gov/newsevents/pressreleases/monetary 20170614c.htm.

${ }^{35}$ In the case of the $\$ 2.3$ trillion reserve balances scenario, purchases of Treasury securities resume at the time of the change in reinvestment policy (2018:Q1),
} 
terms of maturity structure, Treasury securities are purchased in proportion to Treasury issuance.

Turning to liabilities, the longer-run trajectory of the balance sheet is determined primarily by three components. First, as discussed above, the longer-run level of reserve balances is the defining feature of the four scenarios we consider and takes a value of either $\$ 100$ billion, $\$ 500$ billion, $\$ 1$ trillion, or $\$ 2.3$ trillion. Second, we assume that currency grows with nominal GDP. Finally, we assume that paid-in capital grows at an annual rate of 2.6 percent 36

In addition to the aforementioned assumptions about the configuration of the Federal Reserve's balance sheet, the SOMA model requires projected paths of certain macroeconomic variables (e.g., nominal GDP, which determines currency growth) and financial variables (e.g., IOER, Treasury bond rates, and mortgage rates), which are necessary for calculating net interest income generated by the balance sheet. Projections for these variables are produced through stochastic simulations of the FRB/US model 37 For each of the four scenarios, the simulations are based around "modal" paths that are consistent with the March 2017 public version of FRB/US, in which the economy continues to expand. However, these modal paths differ across scenarios because they are influenced by the longer-run size of the balance sheet, which is assumed to affect the term premium on long-term Treasury securities. In turn, the term premium is an input into FRB/US, 38,39 Other things being equal, a lower

as reserve balances are already at their longer-run level. This implies that the balance sheet immediately starts growing at a pace mostly in line with the expansion in key liabilities items such as the value of Federal Reserve notes in circulation and paid-in capital.

${ }^{36}$ Other liabilities - such as the foreign repo pool, overnight reverse repurchase agreements, and the Treasury General Account - also affect the size of the balance sheet. Our assumptions for these liabilities are described in appendix 1.

${ }^{37}$ Our methodology for producing stochastic simulations is the same as that described in the blog post by Ferris et al. (2017), which follows Brayton, Laubach, and Reifschneider (2014).

${ }^{38}$ In FRB/US, yields on long-term Treasury securities are a weighted average of the federal funds rates expected to prevail over the security's term to maturity plus a term premium. The term premium is partly determined endogenously, varying negatively with expected future output gaps, but it also includes an unexplained residual, which can be taken as an input.

${ }^{39}$ The effect of the balance sheet on the term premium is constructed using the estimated model of Li and Wei (2013), which is also the basis for the analyses of 
term premium implies lower long-term interest rates, which have a direct effect on household consumption and business investment (as well as an indirect effect on consumption through increasing the value of stock market and household wealth). The term premium thus influences aggregate demand, which affects the projected paths for all financial and macroeconomic variables that are subsequently fed into the SOMA model. Appendix 2 provides a more detailed account of the interaction between the FRB/US and SOMA models.

Figure 1 shows the size of the Federal Reserve's balance sheet (upper-left panel) and its effect on the term premium (upper-right panel) under the modal path for each of our scenarios. Throughout the paper, securities held in the SOMA portfolio are accounted for at face value, consistent with reporting in the Federal Reserve's H.4.1 statistical release, as also highlighted by Carpenter et al. (2015, p. 261) 40

All else being equal, larger sizes of the balance sheet (as implied by higher longer-run levels of reserve balances) push the term premium down. This results in more accommodative financial conditions that stimulate output and inflation, leading to a higher IOER (lower-left panel). The IOER is tightly linked to the federal funds rate (FFR), which is determined by an inertial Taylor (1999) rule and thus increases in response to a stronger economy and/or higher inflation. The paths for the IOER and FFR, along with the level of the term premium (lower-right panel), play an important role in determining our estimates of the fiscal implications of the Federal Reserve's balance sheet 41

Bonis, Ihrig, and Wei (2017a, 2017b), who assess the effects of Federal Reserve security holdings on term premiums for longer-dated securities. In the model, the composition of assets held by the Federal Reserve affects the supply of longerdated securities to the private sector. The term premium decreases (increases) as these securities become more scarce (available).

${ }^{40}$ Accounting practices for the Federal Reserve follow the principles documented in the Financial Accounting Manual for Federal Reserve Banks, available at https://www.federalreserve.gov/aboutthefed/financial-accountingmanual.htm. Bonis, Fiesthumel, and Noonan (2018) provide a more accessible discussion of the various valuation measures applied to the Federal Reserve's securities holdings.

${ }^{41}$ By using the Li and Wei (2013) model, our approach implies that the size of the Federal Reserve's balance sheet can affect the term premium for a prolonged 


\section{Figure 1. Baseline Paths of Selected Input Variables}

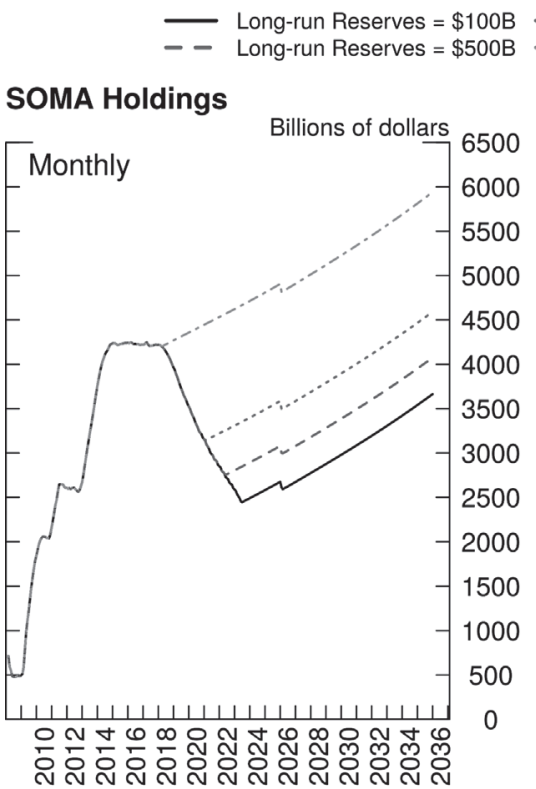

Interest Rate On Excess Reserves
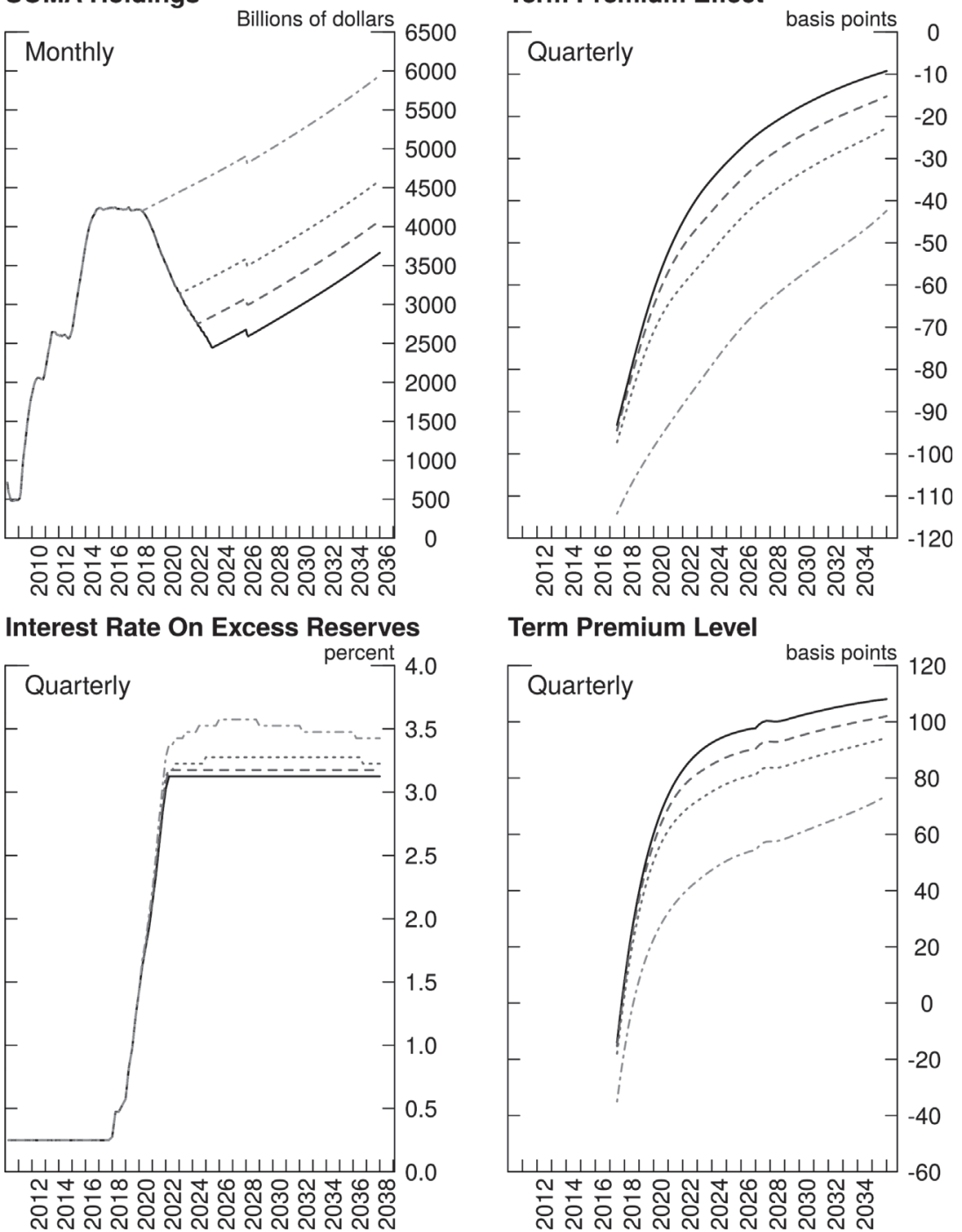

Term Premium Level

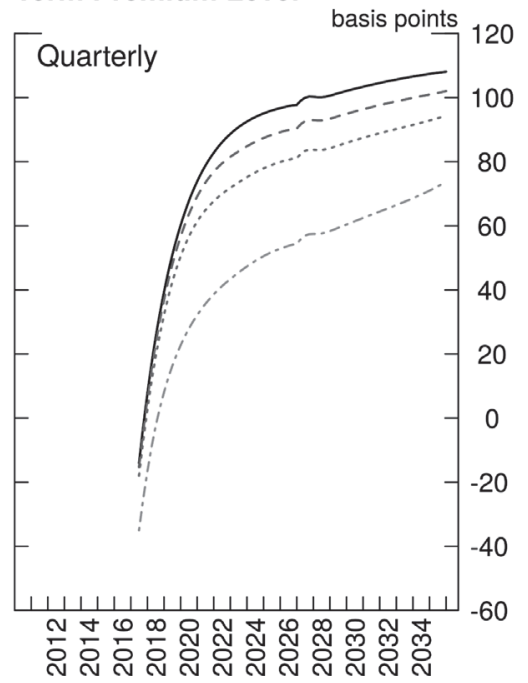




\subsection{Simulation Results}

Our simulations illustrate how the Federal Reserve's balance sheet size influences the level and volatility of the central bank's remittances to the Treasury, as well as its broader fiscal implications (as summarized by the overall effect on federal government debt). We emphasize that, although our results illustrate several general mechanisms by which the balance sheet has fiscal implications, our quantitative findings also depend on several important features of the framework we use. These include (i) how macroeconomic conditions respond to shocks, (ii) the monetary policy rate rule, and (iii) the growth rate of currency in circulation. Moreover, our results are projections and not forecasts. For instance, our assumptions about the evolution of the balance sheet are not meant to preclude the possibility that, in response to a future negative economic shock, reinvestments of maturing securities could restart or additional large-scale asset purchases could take place. Although current Federal Reserve guidance allows for the possibility of such policy responses, we do not attempt to model them, 42

We begin by looking at projected earnings remittances. Table 1 reports summary statistics for each balance sheet scenario, including the average level and variability of remittances, the likelihood of recording a deferred asset and its peak size, and the market value of Federal Reserve assets less interest-bearing liabilities, which is closely related to the notion of central bank insolvency.

\subsubsection{Earnings Remittances: Level and Variability}

Table 1 presents, for each of the four scenarios, the average and standard deviation (across simulations) of annual remittances. Here, we distinguish between what we call the "transition phase" (20172030), during which there are important effects stemming from the

period. Whether the size of the balance sheet can have such long-lasting effects on interest rates is an open question on which we do not take a strong stand. Below we consider simulations in which the balance sheet does not affect the term premium.

${ }^{42}$ See the last bullet of the FOMC's Addendum to the Policy Normalization Principles and Plans: https://www.federalreserve.gov/newsevents/pressreleases/ monetary20170614c.htm 
Table 1. Earnings Remittances and Longer-Run Size of the Balance Sheet (billions of $\$$, unless otherwise noted)

\begin{tabular}{|c|c|c|c|c|}
\hline & \multicolumn{4}{|c|}{$\begin{array}{l}\text { Longer-Run Level of } \\
\text { Reserve Balances } \\
\quad(\text { billions of } \$)\end{array}$} \\
\hline & $\$ 100$ & $\$ 500$ & $\$ 1,000$ & $\$ 2,300$ \\
\hline \multicolumn{5}{|l|}{ Avg. Remittances } \\
\hline \multicolumn{5}{|l|}{ Dollar Values } \\
\hline $2017-2030$ & 66.8 & 67.2 & 67.3 & 63.8 \\
\hline $2031-2035$ & 111.8 & 113.7 & 115.6 & 118.2 \\
\hline \multicolumn{5}{|l|}{ Per Balance Sheet Dollar* } \\
\hline $2017-2030$ & 2.2 & 2.0 & 1.8 & 1.3 \\
\hline $2031-2035$ & 3.1 & 2.9 & 2.6 & 2.0 \\
\hline \multicolumn{5}{|l|}{ Std. Dev. Remittances } \\
\hline \multicolumn{5}{|l|}{ Dollar Values } \\
\hline $2017-2030$ & 11.1 & 11.8 & 14.4 & 25.8 \\
\hline $2031-2035$ & 21.2 & 20.6 & 22.0 & 33.2 \\
\hline \multicolumn{5}{|l|}{ Per Balance Sheet Dollar* } \\
\hline $2017-2030$ & 0.3 & 0.3 & 0.4 & 0.5 \\
\hline $2031-2035$ & 0.5 & 0.4 & 0.5 & 0.6 \\
\hline \multicolumn{5}{|l|}{ PDV of Remittances** } \\
\hline Avg. & 563.4 & 558.0 & 547.8 & 493.1 \\
\hline Std. Dev. & 141.5 & 141.4 & 142.6 & 153.9 \\
\hline \multicolumn{5}{|l|}{ Deferred Asset } \\
\hline Probability of Incurring* & 3.9 & 4.1 & 4.6 & 30.8 \\
\hline 95th Percentile of Size & 0.0 & 0.0 & 0.0 & 30.6 \\
\hline Maximum Realized Spell*** & 14 & 14 & 15 & 29 \\
\hline $\begin{array}{l}\text { 5th Percentile of Market } \\
\text { Value of Assets Less } \\
\text { Interest-Bearing Liabilities } * * * *\end{array}$ & 817.0 & 820.7 & 826.7 & 841.6 \\
\hline \multicolumn{5}{|l|}{$\begin{array}{l}* \text { Expressed in percent } \\
\text { ** PDV: present discounted value } \\
* * * \text { Expressed in quarters } \\
* * * * \text { Minimum across periods }\end{array}$} \\
\hline
\end{tabular}


Figure 2. Average Annual Remittances
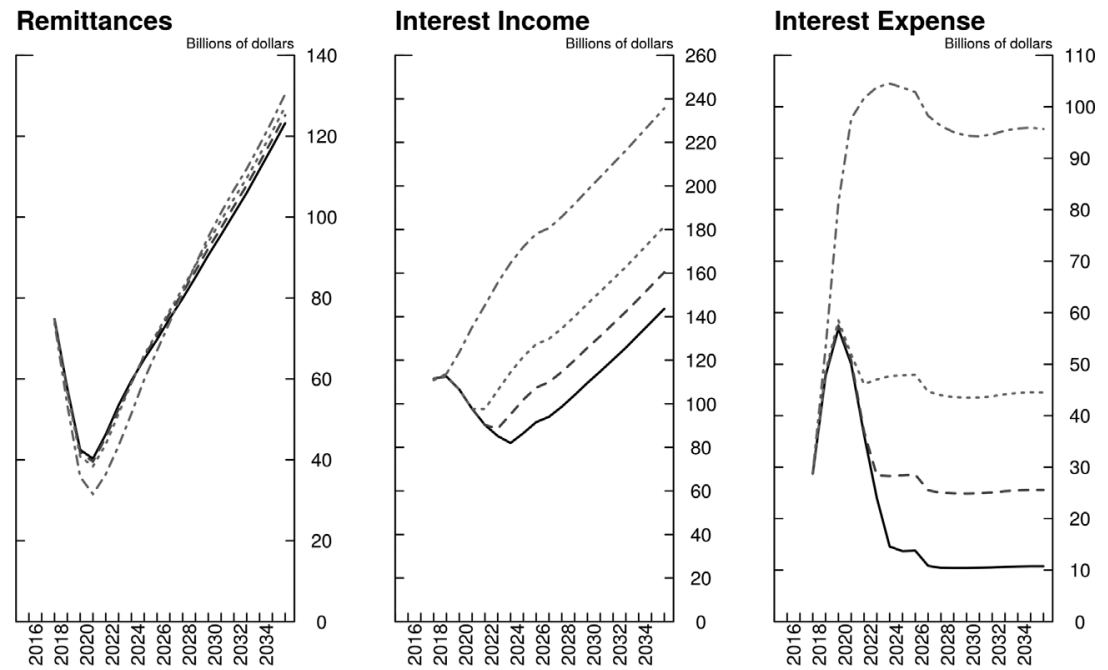

$\begin{array}{llll}- & \text { Long-run Reserves }=\$ 100 \mathrm{~B} & \cdots & \text { Long-run Reserves }=\$ 1 \mathrm{~T} \\ -- & \text { Long-run Reserves }=\$ 500 \mathrm{~B} & -- & \text { Long-run Reserves }=\$ 2.3 \mathrm{~T}\end{array}$

projected rise in interest rates from initially low levels to their longerrun level, and the "longer run" (2031-2035) 43 During the transition phase, we observe that remittances (in dollars) are smaller and more variable for the scenario with the largest longer-run balance sheet (column 4) relative to the others. But, in the longer run, both the amount and variability of remittances increase with balance sheet size.

Figure 2 shows average (across simulations) annual remittances, interest income, and interest expense for each of the four scenarios from 2017 to 2035. In each case, average remittances decrease in the near term before increasing thereafter. The initial decrease is largely driven by higher interest expenses paid on reserves. These rise sharply, as short-term interest rates are projected to increase faster than the decline in reserve balances. In addition, under the largest balance sheet scenario, interest expense is further boosted

\footnotetext{
${ }^{43}$ Although the projected increase in interest rates occurs during the first few years, the effect on remittances persists further because Federal Reserve asset purchases remain on the balance sheet for a long time. The "longer-run" results are meant to capture differences across scenarios once the effects of the rising interest rate have mostly dissipated.
} 
by more accommodative financial conditions, which result in higher inflation and short-term interest rates. By contrast, interest income is less responsive to the prevailing level of interest rates through the medium term because it mostly reflects fixed coupon interest produced by long-term legacy assets. The subsequent increase in remittances reflects the fact that, once the longer-run level of reserve balances is reached, the Federal Reserve begins to purchase higher-yielding assets 44 In the longer run, purchased assets allow the Federal Reserve to earn, on average, positive net income because the yield curve is typically upward sloping and the central bank issues very short-term liabilities to finance relatively longer-dated securities.

Looking across scenarios, both income and expenses increase with the balance sheet size. However, for roughly the first ten years of the projection period, average remittances are actually smallest in the $\$ 2.3$ trillion reserve balances scenario. This result is driven by two factors. First, maintaining a constant level of reserves implies buying securities while the term premium is negative, which implies that these securities are expected to generate negative net income and reduce future remittances. Second, varying the size of the balance sheet has general equilibrium effects. A larger balance sheet implies a lower term premium - that is, new asset purchases will generate lower interest income - and also stimulates the economy, leading, ceteris paribus, to greater interest expenses (through a higher IOER) 45 Turning to the longer run, average remittances increase in balance sheet size as the aforementioned general equilibrium effects only partly offset the greater net interest income implied by a larger balance sheet and a positive term premium.

\footnotetext{
${ }^{44}$ This occurs at a different time for each scenario: in 2018 for the $\$ 2.3$ trillion scenario, 2021 for the $\$ 1$ trillion scenario, 2022 for the $\$ 500$ billion scenario, and 2023 for the $\$ 100$ billion scenario.

${ }^{45}$ The general equilibrium effects also lead to faster nominal GDP and currency growth, which work toward increasing remittances through two main channels. First, a faster pace of currency growth implies that a larger portion of the balance sheet is funded by non-interest-bearing liabilities. Second, for a given level of reserves, faster currency growth implies that the Federal Reserve needs to step up its pace of purchases of Treasury securities, which ultimately generates additional interest income. However, these channels are quantitatively less important than the general equilibrium effects that lead to higher interest expense and thus reduce remittances.
} 
To get a sense of the quantitative importance of the general equilibrium effects, we also ran simulations that "shut off" the effect of the balance sheet on the term premium. (Consequently, these simulations only reflect the direct effects on remittances of changes in the Federal Reserve's assets and liabilities and not those stemming from endogenous changes in interest rates.) We find that average remittances are weakly increasing with the size of the balance sheet both in the transition period and in the longer run. This is in stark contrast to the results shown in table 1 . We conclude that general equilibrium effects are very important.

Cumulative nominal remittances over the entire projection period are estimated to be about $\$ 18$ billion lower under the largest balance sheet scenario than they are under the smallest one. Table 1 reports that the difference in the present discounted value of remittances across these two scenarios is even greater, at around $\$ 70$ billion. This occurs because years further in the future - when the larger balance sheet produces relatively higher remittances - are discounted more heavily and also because the paths for the IOER are higher under the larger balance sheet scenario, leading to greater discounting 46

Turning to the variability of remittances, the upper and middle rows of panels in figure 3 plot, for each of the four scenarios, time series of the annual standard deviation (across simulations) of interest income, interest expense, and remittances for each scenario. Interest income (shown in the upper-left panel) displays essentially no variability prior to balance sheet normalization (i.e., when reserve balances reach their longer-run level) because income mostly reflects the coupon interest of assets purchased in the past. As new securities are purchased - starting in 2018 for the $\$ 2.3$ trillion scenario, 2021 for the $\$ 1$ trillion scenario, 2022 for the $\$ 500$ billion scenario, and 2023 for the $\$ 100$ billion scenario - the variability of interest income increases and is greater (both across scenarios and over time) the larger is the size of the balance sheet. The dispersion of interest income reflects both differences in the quantities (and

\footnotetext{
${ }^{46}$ We calculate the present discounted value (PDV) of remittances by discounting the projected stream of remittances from 2017 through 2035 using the (compounded) IOER, and we report, for each of the four scenarios, the average and standard deviation (across simulations) of the PDV.
} 


\section{Figure 3. Standard Deviation of Annual Remittances}

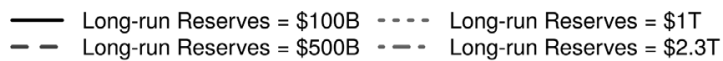

Interest Income

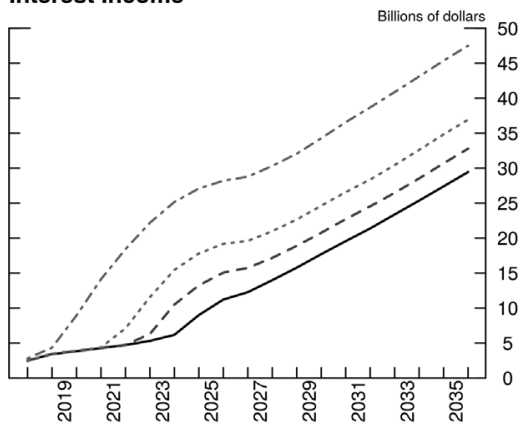

Remittances

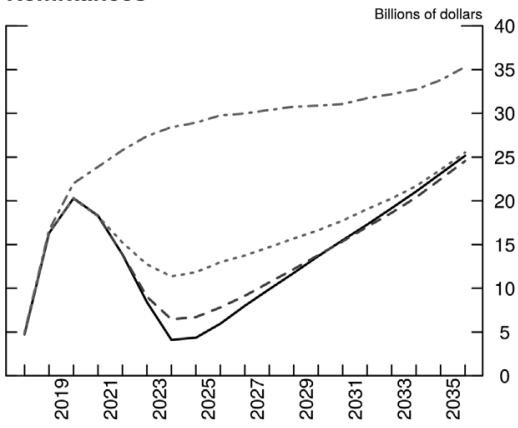

Decomposition: Variance Factor

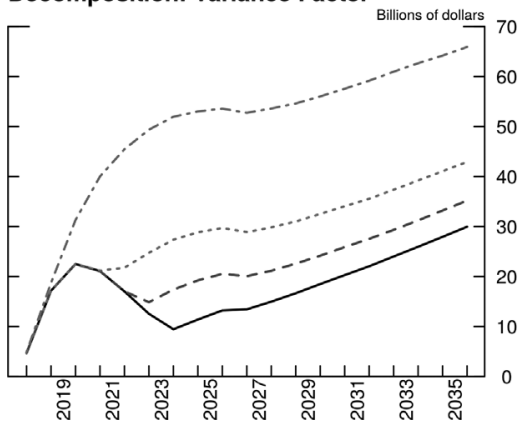

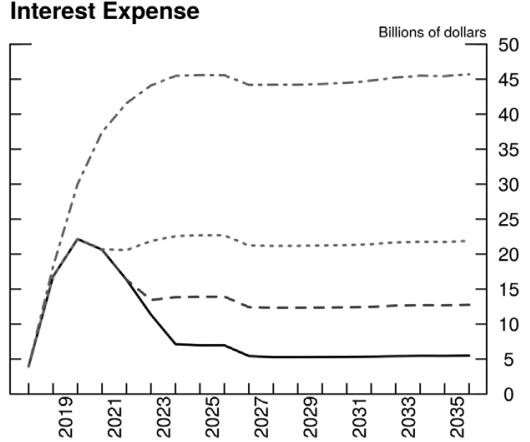

Decomposition: Covariance Factor

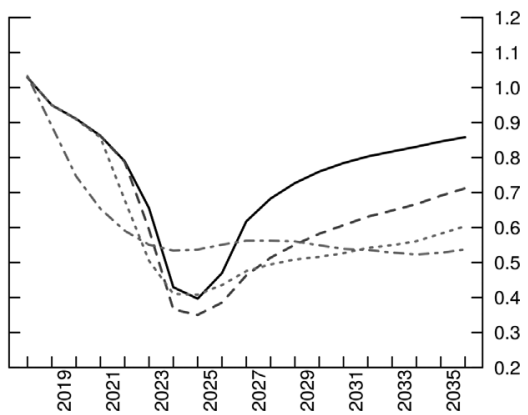


composition) of assets purchased and differences in market interest rates at the time of purchase. Likewise, the dispersion in interest expense (upper-right panel) reflects variability across simulations in both the quantity of interest-bearing reserves and the level of shortterm interest rates. For a given variance in short-term interest rates, a larger quantity of reserves implies more variable interest expense. This largely explains the variation, across both time and scenarios, of the dispersion of interest expense.

The variability of remittances (middle panel of figure 3) largely reflects the variability of net interest income, which in turn reflects the variability of interest income and interest expense as well as their covariance 47 Prior to the resumption of asset purchases, the variability of remittances mirrors that of interest expense because the variability of income is essentially zero and, hence, so is the covariance. However, after asset purchases resume, the covariance between interest income and interest expense becomes non-negligible. This covariance (across simulations) is generally positive and can be quite large, reflecting the feature that short- and long-term interest rates tend to move together. For example, in the $\$ 1$ trillion scenario, the variability of remittances actually decreases from 2020 to 2024 even though the variability of both interest income and expense is increasing. Looking across scenarios, the volatility of remittances is roughly similar for the small-to-intermediate reserve balances scenarios, but it increases substantially if reserve balances remained at $\$ 2.3$ trillion.

To gain some additional insight, we decompose the variance of net interest income, $(I-E)$, as follows:

$$
\begin{aligned}
& \operatorname{Var}(I-E) \\
& \quad=\operatorname{Var}(I)+\operatorname{Var}(E)-2 \cdot \operatorname{Corr}(I, E) \cdot[\operatorname{Var}(I) \cdot \operatorname{Var}(E)]^{0.5} \\
& \quad=[\operatorname{Var}(I)+\operatorname{Var}(E)] \cdot\left\{1-\frac{2 \cdot \operatorname{Corr}(I, E)}{\left[\frac{\operatorname{Var}(I)}{\operatorname{Var}(E)}\right]^{0.5}+\left[\frac{\operatorname{Var}(E)}{\operatorname{Var}(I)}\right]^{0.5}}\right\} .
\end{aligned}
$$

\footnotetext{
${ }^{47}$ Technically, remittances equal net interest earnings less non-interest expense and dividends, but the latter two components contribute little to variability. In addition, remittances are restricted to be non-negative (i.e., if net interest earnings are negative, remittances are set to zero, and a deferred asset is recorded). If the Federal Reserve has a deferred asset, then any subsequent positive net earnings are used to pay down that asset rather than being remitted.
} 
We refer to the first bracketed term as the "variance factor" and to the second as the "covariance factor." The standard deviation of remittances (middle panel of figure 3) is roughly the product of the square roots of the variance and covariance factors (lower row of figure 3). The lower-left panel shows that larger longer-run reserve balances uniformly increase the variability of remittances by increasing the sum of the variances of interest income and expense. On the other hand, the covariance factor (lower-right panel) does not uniformly vary with the balance sheet size. It depends on both the (across-simulation) correlation between interest income and expense and the relative variability of income and expense. Whereas the former is increasing in the longer-run size of the balance sheet, the latter is not.

Although the longer-run (2031-2035) variability of remittances is roughly similar for the small-to-intermediate balance sheet scenarios (as displayed in figure 3 and table 1), the variability of remittances will be increasing in size once all transition effects have dissipated (i.e., in the true long run). As the balance sheet continues to grow, the share of interest-paying liabilities will shrink, as reserve balances remain at their longer-run level and currency continues to grow. Thus, the variability of interest expense relative to that of interest income will also shrink toward zero, meaning that the covariance factor will eventually converge to 1 for all scenarios. The variability of remittances will then be determined exclusively by the sum of variances of income and expense, which is increasing in reserve balances.

Finally, table 1 also reports the average and standard deviation of remittances per balance sheet dollar. These measures give an indication about the rate of return on central bank assets and the variability of that return. The average rate of return decreases with the longer-run size of the balance sheet. This is driven, in part, by the fact that a larger balance sheet will have a smaller fraction of assets backed by currency - that is, a greater fraction of assets will be backed by interest-bearing reserves. The variability of the return, on the other hand, varies little across scenarios.

\subsubsection{Deferred Assets}

Table 1 also reports summary statistics for deferred assets for each scenario, including (i) the likelihood of recording a deferred asset 


\section{Figure 4. Likelihood and Size of Deferred Assets}

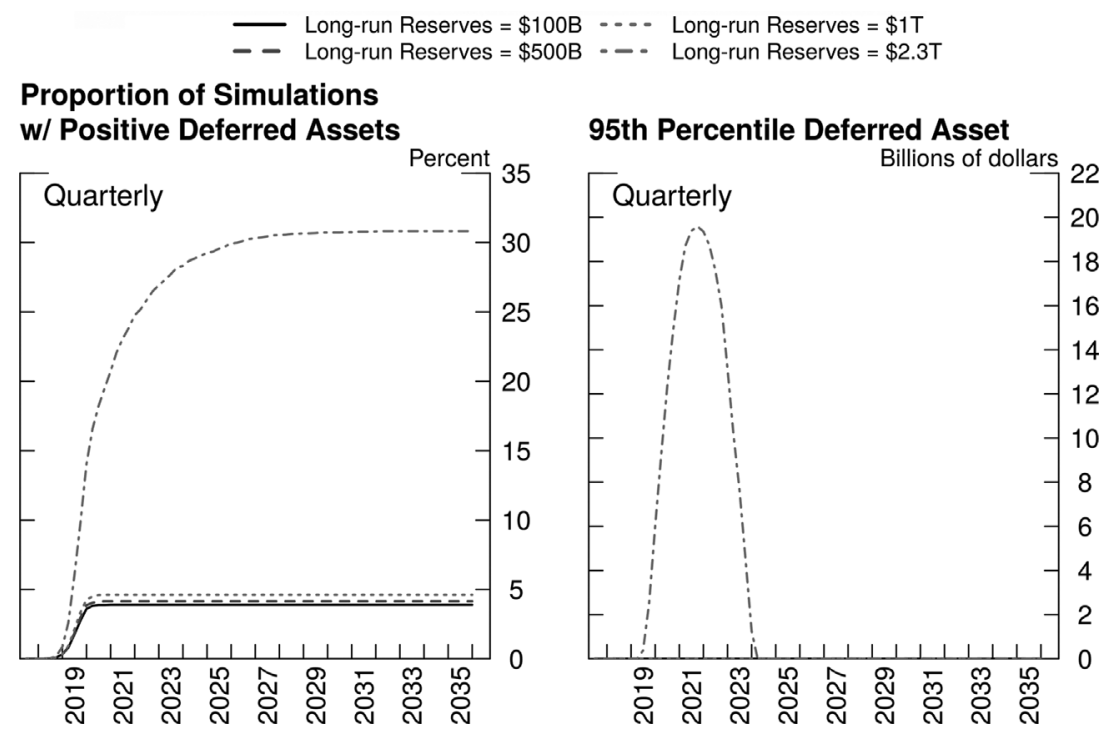

(i.e., the fraction of simulations featuring negative net earnings in at least one quarter); (ii) the maximum (across periods) of the 95th percentile of its size (across simulations); and (iii) the maximum realized spell length (in quarters). All three measures are demonstrably higher in the $\$ 2.3$ trillion scenario than in the cases with smaller balance sheets.

The left panel of figure 4 plots the cumulative share of simulations for each scenario that have experienced a positive deferred asset. (That is, in a given quarter, it plots the share of simulations that produced a deferred asset in any quarter prior to and including that quarter.) The change in the cumulative share measures how many simulations are experiencing a positive deferred asset for the first time. Losses are most common in 2018 and 2019, when short-term interest rates are projected to be rising. For the smallto-intermediate reserves scenarios, interest income declines as the balance sheet shrinks, while interest expense increases (at least initially as the increase in the IOER more than offsets any reduction in reserve liabilities). By contrast, the large reserves scenario 
(\$2.3 trillion) yields many simulations in which a deferred asset is first recorded between 2020 and 2022. This result arises because purchasing additional securities while the term premium is negative implies that those securities are expected to generate negative net income over time 48 The larger are the purchases of such securities, the greater are the odds of booking a deferred asset. Specifically, moving from the $\$ 1$ trillion to the $\$ 2.3$ trillion scenario increases these odds from roughly 5 percent to over 30 percent.

The right panel of figure 4 plots the size of the deferred asset as measured by the 95th percentile of the distribution-which can be loosely interpreted as a "value at risk" measure for the Federal Reserve 49 Because the probability of recording a deferred asset is less than 5 percent for scenarios in which longer-run reserve balances are less than $\$ 1$ trillion, the plotted size of the deferred asset is zero in these cases. For the large balance sheet scenario, on the other hand, the deferred asset can be as large as $\$ 30$ billion.

\subsection{3 (In)Solvency}

As explained above, the Federal Reserve would be "insolvent" if the EPDV of remittances to the Treasury is ever negative. In this unlikely case, the central bank would be expected to need recapitalization from the Treasury at some point in the future or to resort to "printing money." As noted earlier, the EPDV of remittances equals the sum of the Federal Reserve's tangible and intangible wealth. Tangible wealth is the market value of the Federal Reserve's assets less the value of its interest-bearing liabilities, and intangible wealth is the EPDV of future seigniorage. Although intangible wealth is

\footnotetext{
${ }^{48}$ As shown in figure 1 , the level of the term premium under the modal path for the $\$ 2.3$ trillion reserve balance scenario is negative through the end of 2018 .

49 "Value at risk" (VaR) is a measure of the risk of a given portfolio over a set horizon. For example, a one-day 5 percent $\mathrm{VaR}$ of $\$ 1$ million means there is a 0.05 probability that the portfolio will fall in value by more than $\$ 1$ million over a one-day period. In our case, the right panel of figure 4 plots threshold values such that the probability of cumulative negative net earnings on the Federal Reserve's balance sheet exceeding these values is 0.05. Christensen, Lopez, and Rudebusch (2015) is one study that takes a probabilistic approach to examining the interest rate risk inherent in the SOMA portfolio.
} 
difficult to estimate, we do have all of the information we need to calculate tangible wealth in our simulations 50

Table 1 reports the minimum (across periods) of the Federal Reserve's tangible wealth (as measured by the 5th percentile of the distribution) for each scenario. Here, we see that the minimum of tangible wealth is weakly increasing in the balance sheet size. One may expect the lowest values of tangible wealth to occur for the large ( $\$ 2.3$ trillion) balance sheet scenario since it is associated with the largest realizations of deferred assets and unrealized capital losses such that the market value of assets can be significantly below book value. However, this shortfall is more than offset by the fact that non-interest-bearing liabilities (mostly currency) are much larger in this scenario. In the model, all else being equal, a larger balance sheet acts to stimulate the economy, and currency grows at the rate of nominal GDP. Finally, across all of our scenarios and simulations, tangible wealth is always substantially above zero. Assuming that the EPDV of seigniorage is positive, we conclude that Federal Reserve insolvency is an extremely remote possibility under all of our balance sheet scenarios.

\subsubsection{Broader Fiscal Implications}

We have so far focused on potential outcomes for Federal Reserve earnings remittances (and related measures). However, remittances provide an incomplete characterization of the overall fiscal implications of longer-run balance sheet sizes. All else being equal, different balance sheet sizes prompt more or less accommodative financial conditions depending on the portfolios' overall duration. Different financial conditions can affect the pace of economic growth and thus the level of nominal tax receipts, ultimately influencing the overall fiscal position of the federal government in terms of budget balances and outstanding debt.

\footnotetext{
${ }^{50}$ Specifically, the market value of assets is simply book value plus (minus) any unrealized capital gain (loss) and less the value of any deferred asset, while the value of interest-bearing liabilities is calculated by subtracting currency and capital from total liabilities.
} 


\section{Table 2. Broader Fiscal Implications of the Longer-Run Size of the Balance Sheet (billions of $\$$, unless otherwise noted)}

\begin{tabular}{|l|c|c|c|c|}
\hline & \multicolumn{3}{|c|}{$\begin{array}{c}\text { Longer-Run Level of } \\
\text { Reserve Balances } \\
\text { (billions of \$) }\end{array}$} \\
\cline { 2 - 5 } & $\mathbf{3 1 0 0}$ & $\mathbf{\$ 5 0 0}$ & $\mathbf{\$ 1 , 0 0 0}$ & $\mathbf{\$ 2 , 3 0 0}$ \\
\hline Federal Government Debt, & & & \\
$\quad$ End-2035 (Avg.) & 34,464 & 34,429 & 34,384 & 34,260 \\
Nominal Outstanding & 84.1 & 83.9 & 83.6 & 82.7 \\
Ratio to GDP* & & & & \\
Nominal Cumulative (2017-2035) & 1,495 & 1,509 & 1,520 & 1,483 \\
$\quad$ (Avg. across Simulations) & 2,351 & 2,365 & 2,383 & 2,425 \\
Federal Reserve Remittances & 138,886 & 139,054 & 139,282 & 139,946 \\
Federal Budget Surplus & 136,534 & 136,689 & 136,900 & 137,521 \\
Federal Tax Receipts & & & & \\
Federal Outlays & 27,242 & 27,317 & 27,416 & 27,700 \\
$\quad$ of which: & & & \\
$\quad$ Interest Expense & \multicolumn{3}{|c|}{} \\
\hline * Expressed in percent & & & & \\
\hline
\end{tabular}

We use the FRB/US model to evaluate these broader fiscal effects 51 Table 2 presents projections for key fiscal variables generated by the model, including federal government debt at the end of 2035 (expressed both in nominal dollars and relative to GDP) as well as nominal cumulative federal budget surpluses, tax receipts, and outlays 52 For comparison, we also include projected cumulative

\footnotetext{
${ }^{51}$ We want to stress that our analysis does not speak to the overall fiscal effects of quantitative easing, as all of our scenarios start from the same initial conditions (as of 2017:Q1). To assess such effects, one would have to consider a counterfactual scenario in which reserve balances did not increase following the Great Recession. See Engen, Laubach, and Reifschneider (2015) for an analysis of the benefits of the Federal Reserve's unconventional monetary policies.

${ }^{52}$ The federal government budget surplus is equal to the difference between tax receipts and outlays. Tax receipts are the sum of personal income tax and nontax receipts, corporate income tax accruals, indirect business tax receipts, social insurance tax receipts, and income receipts on assets and dividends. Outlays are the sum of federal government consumption expenditure, net interest, and
} 
Federal Reserve remittances. We stress two main takeaways. First, the broader fiscal implications of different balance sheet sizes are much larger than the corresponding implications for remittances. Second, on average, a larger balance sheet produces substantial net fiscal benefits, although it produces somewhat lower remittances.

To illustrate the first result, we consider the difference between the maximum and minimum values of each variable across longer-run balance sheet sizes. The range for cumulative remittances (comparing columns 3 and 4 ) is a little less than $\$ 40$ billion, while the range for other variables is noticeably larger. For example, the range for surpluses (comparing columns 1 and 4 ) is nearly $\$ 75$ billion, and the corresponding range for end-of-simulation government debt is about $\$ 205$ billion.

In terms of the second result, note that moving from the small balance sheet scenario ( $\$ 100$ billion, column 1) to the large balance sheet scenario ( $\$ 2.3$ trillion, column 4 ) reduces average outstanding debt by over $\$ 200$ billion - a decrease that is equivalent to about a 1.4 percentage point reduction in the debt-to-GDP ratio. This is the result of the large balance sheet scenario involving substantially more tax revenues (about $\$ 1.1$ trillion) over the simulation horizon 53 Thus, although cumulative remittances are $\$ 12$ billion lower under the large scenario, this difference is swamped by the overall effect on the government budget position.

An important caveat of the results concerning the overall fiscal implications is that they hinge on the assumptions on interest rate policy. Specifically, inertia in the policy rule implies that the additional financial accommodation provided by a larger balance sheet is not perfectly offset by the slow increase in short-term interest rates. This results in higher output for some time and, in turn, higher cumulative tax receipts. Under less inertial policies, a larger balance

other transfer payments. In turn, federal government consumption expenditure is the sum of federal government employee compensation and non-compensation consumption expenditure. Finally, other transfer payments include net transfer payments, subsidies less surplus, and grants-in-aid to state and local governments.

${ }^{53}$ Increased tax receipts reflect greater economic output, which results from lower long-term interest rates associated with a large balance sheet. Increased interest expense primarily reflects higher shorter-term (less than five-year) interest rates because much of the government debt takes the form of shorter-term securities. 
sheet would not be expected to boost the overall economy as much. In this case, different longer-run balance sheet sizes would produce fairly similar effects for the overall government budget position but starker differences for remittances. The larger balance sheets would be associated with even higher paths for the IOER than shown in our simulations, leading to lower remittances.

\subsubsection{Updated Simulations}

Thus far, our simulation results have been relative to scenarios constructed before the start of the Federal Reserve's balance sheet normalization program. Specifically, the scenarios above start with the size of the balance sheet as of the first quarter of 2017. Here, we update our simulation results after taking into account the subsequent evolution of the balance sheet. The balance sheet normalization program was initiated in October 2017, and, as of June 2018, central bank reserve balances stood near $\$ 1.9$ trillion. The decrease over the subsequent five quarters reflects some balance sheet runoff and an increase in nonreserve liabilities.

We again consider four scenarios: a "large" scenario, which maintains the June 2018 level of reserves (\$1.9 trillion) into the longer run, and our three smaller scenarios with longer-run reserves of $\$ 100$ billion, $\$ 500$ billion, and $\$ 1.0$ trillion. In addition to the new start date, we update our model assumptions to be consistent with both median expectations from the Federal Reserve Bank of New York's surveys and the public version of the FRB/US model as of June 2018. Appendix 1 highlights the key revised assumptions.

Our results are qualitatively (and, for the most part, quantitatively) similar to those reported above. The most notable difference is that the probability of booking a deferred asset for the scenario in which reserve balances stay at their initial level drops from 30 percent to 3 percent. This drastic reduction can be accounted for by three factors: (i) the lower longer-run level of reserve balances (i.e., $\$ 1.9$ trillion rather than $\$ 2.3$ trillion); (ii) updated assumptions for nonreserve liability items; and (iii) the later start date for the projections. The lower level of longer-run reserves accounts for about half of the decline. Updated assumptions for liability itemssuch as a higher balance for the Treasury General Account, which results in greater non-interest-bearing liabilities - account for about 
one-fourth. The rest of the decline occurs because the increase in the IOER from March 2017 to June 2018 has been gradual and near the modal path of the stochastic simulations considered above. This means that some of the stochastic simulations that feature highIOER paths - i.e., those that are also associated with low remittances and a higher probability of a deferred asset - have not been realized. It is also interesting to note that the second and third factors (i.e., updated assumptions and the later projection start date) also affect the smaller reserve balances scenarios (i.e., $\$ 1$ trillion or less), for which the probability of booking a deferred asset falls from around 4 percent (table 1) to below 1 percent.

\section{Conclusions}

This paper simulated the transition of the Federal Reserve's balance sheet to four alternative longer-run sizes in an effort to understand the fiscal implications for both remittances and broader economic activity. Our approach used a large-scale macroeconomic model (FRB/US) to generate future paths of financial and macroeconomic variables and allows for the central bank's balance sheet to provide (or remove) monetary accommodation. The simulation results suggest the following takeaways: (i) maintaining reserve balances of $\$ 2.3$ trillion would have been associated with a significant likelihood of zero remittances (and a deferred asset) in the coming years (30 percent); (ii) shrinking reserve balances to a longer-run level of $\$ 1.0$ trillion (or less) would markedly reduce the likelihood of zero remittances to less than 5 percent; and (iii) the likelihood of the Federal Reserve not being able to cover its losses with future seigniorage, and therefore requiring recapitalization from the Treasury, is extremely remote. We stress that these results are based entirely on the FRB/US model. Future research can assess whether its lessons are robust to the use of different macroeconomic models and assumptions.

\section{Appendix 1. Assumptions Underlying Simulations}

Our simulations require two main inputs: assumptions about the configuration of the balance sheet and projected paths for financial and macroeconomic variables. We discuss each in turn. 
(i) Assumptions about the configuration of the Federal Reserve's balance sheet: Our initial condition is the configuration at the end of 2017:Q1.

- Assumptions about the asset side:

- No asset sales at any point in time;

- Treasury and agency debt holdings roll off the SOMA portfolio at maturity;

- Agency MBS prepayments are determined through a model developed by staff at the Federal Reserve Board. The model is a simplified version of the framework proposed in Richard and Roll (1989) for projecting prepayment rates 54

- Full reinvestments of maturing securities and principal repayments are expected to cease at the beginning of January 2018,55

- Consistent with the FOMC's June 2017 Addendum to the Policy Normalization Principles and Plans, once full reinvestments are ceased, principal repayments received from Treasury and agency securities held in the SOMA portfolio will be reinvested only to the extent that those payments exceed gradually rising dollar caps 56 Once the caps reach their respective maximums, they will remain in place until the size of the balance sheet is "normalized" that is, when reserve balances reach their longer-run level;

- Once the size of the balance sheet is normalized, purchases of Treasury securities resume to

\footnotetext{
${ }^{54}$ Carpenter et al. (2015, pp. 260-61) and Bonis, Kandrac, and Pardue (2017) provide more detail on the prepayment model, which is essentially used to capture the effect of interest rates on the paydown path of SOMA MBS holdings.

${ }^{55}$ This assumption is in line with expectations drawn from the June 2017 Federal Reserve Bank of New York's Survey of Primary Dealers and Survey of Market Participants. See https://www.newyorkfed.org/markets/primarydealer survey_questions.html and https://www.newyorkfed.org/markets/survey_ market_participants.html.

${ }^{56}$ The evolution of the caps is as specified in the addendum. See https://www. federalreserve.gov/newsevents/pressreleases/monetary20170614c.htm
} 
accommodate the expansion of key nonreserve liability items such as currency in circulation, capital paid-in, and reverse repurchase agreements, 57

- After the normalization of the size of the balance sheet, purchases of Treasury securities will be spread across the maturity spectrum in equal proportions to Treasury issuance. In turn, the maturity structure of Treasury issuance reflects the issuance pattern(s) from auctions at the beginning of the projection period.

- Assumptions about the liability side:

- Currency in circulation grows with nominal GDP;

- Paid-in capital grows at an annual rate of 2.6 percent 58

- Foreign repo (RP) pool: reverse repurchase agreements (repos) associated with foreign official and international accounts: set to $\$ 200$ billion, consistent with the median expectation from the June 2017 surveys;

- Overnight Reverse Repurchase (ON RRP): constant at $\$ 100$ billion through the end of 2025, and zero thereafter 59

- Treasury General Account (TGA): constant at $\$ 150$ billion, consistent with the U.S. Treasury's stated minimum;

\footnotetext{
${ }^{57}$ Treasury securities are also purchased to replace roll-offs of agency MBS as MBS continue to pay down.

${ }^{58}$ Our assumption for capital is based on the growth rate implied by the corresponding level expected to prevail in 2025 by the median respondent to the June 2017 Survey of Primary Dealers and Survey of Market Participants. This assumption is also consistent with that made in the July update to the 2017 SOMA Annual Report. See https://www.newyorkfed.org/markets/annual_reports.html

${ }^{59}$ This assumption is consistent with the median expectation from the June 2017 surveys for the 2025 level of ON RRPs. Thereafter, it follows the policy normalization principles as outlined by the FOMC: "The Committee will use an overnight reverse repurchase agreement facility only to the extent necessary and will phase it out when it is no longer needed to help control the federal funds rate." See Policy Normalization Principles and Plans, September 17, 2014, available at http://www.federalreserve.gov/newsevents/press/monetary/20140917c.htm.
} 
- Other deposits: constant at $\$ 40$ billion, consistent with the median expectation from the June 2017 surveys for the 2025 level 60

- Along with our assumptions on the longer-run level of reserves - either $\$ 100$ billion, $\$ 500$ billion, $\$ 1$ trillion, or $\$ 2.3$ trillion - the items above determine the longer-run size of the balance sheet.

(ii) Projected paths for financial and macroeconomic variables that affect the evolution of the balance sheet and the income it generates.

- Paths of financial and macroeconomic variables - most importantly, interest rates and nominal GDP-are generated by running stochastic simulations of the FRB/US model;

- Stochastic simulations are based around modal paths consistent with (i.e., identical to, but with one necessary exception) the March 2017 public version of FRB/US;

- The exception arises because the modal paths are influenced by the longer-run balance sheet; as we vary its size across scenarios, the term premium is altered, and this in turn affects the rest of the economy;

- Shocks relative to the modal paths are held constant across scenarios;

- For each scenario, we conduct 5,000 simulations from 2017 through 2035.

\section{Updated Assumptions for June 2018 Simulations}

Our updated simulations described in section 3.2.5 use the same assumptions as above with the following exceptions:

\footnotetext{
${ }^{60}$ This item includes deposits held at the Reserve Banks by international and multilateral organizations, government-sponsored enterprises, and designated financial market utilities. It also includes certain deposit accounts other than the Treasury General Account for services provided by the Reserve Banks as fiscal agents of the United States. See https://www.federalreserve.gov/releases/h41/ current/
} 
- The initial condition for the configuration of the Federal Reserve's balance sheet is now its status at the end of 2018:Q2.

- Assumptions about the liability side were updated to bring them in line with the median outcomes from the June 2018 Survey of Primary Dealers and Survey of Market Participants for the item levels expected to prevail in 2025:

- Paid-in capital grows at an annual rate of 3 percent;

- Foreign RP pool: set to $\$ 220$ billion;

- Treasury General Account (TGA): constant at $\$ 300$ billion;

- Other deposits: constant at $\$ 85$ billion.

- For the projected paths for financial and macroeconomic variables:

- Stochastic simulations are based around modal paths consistent with the June 2018 public version of FRB/US;

- For each scenario, we conduct 5,000 simulations from 2018 through 2035.

\section{Appendix 2. Interactions between the SOMA and the FRB/US Models}

In this appendix, we discuss in more detail the features of the FRB/US model that interact more prominently with the SOMA model. The FRB/US model is a large-scale estimated general equilibrium model of the U.S. economy. Detailed descriptions of the model are Brayton and Tinsley (1996), Brayton et al. (1997) and, more recently, Chung et al. (2012) 61 Here, we highlight the building blocks of the model that are most relevant to our analysis.

The model takes into account decisions in three sectors: the household sector, the private business sector, and the public sector. Many of these decisions depend crucially on interest rates faced by the decisionmakers, for which the rates that are directly relevant for their decisions are long-term interest rates.

The FRB/US model includes three long-term government bonds: a five-year, a ten-year, and a thirty-year bond. Interest rates on these bonds are determined according to the expectations theory of the

\footnotetext{
${ }^{61}$ Full documentation of the model is available at https://www.federalreserve. gov/econres/us-models-about.htm
} 
term structure and are thus specified as a weighted average of future values of the short-term policy rate (i.e., the federal funds rate) expected to prevail over the bond's term to maturity, plus a term premium to compensate for the difference in risk exposure from holding the bond instead of a sequence of short-term assets. Term premiums for the three government bonds are partly determined endogenously, as they vary countercyclically with a weighted average of the output gap expected over the maturity of the bonds but also have an unexplained residual, which can be taken as an input. As explained in the body of the paper, we assume that the Federal Reserve's balance sheet affects the term premium on long-term bonds according to the estimated $\mathrm{Li}$ and Wei (2013) model. Changes to term premiums in turn affect long-term interest rates, which directly influence aggregate demand through consumption and investment decisions.

In the public sector, monetary policy is characterized by an equation for the level of the federal funds rate, which is determined by an inertial Taylor (1999) rule. The federal funds rate responds to deviations of inflation from an inflation target and to deviations of aggregate output from its potential level (i.e., the output gap). Stronger aggregate demand leads to a higher output gap and inflation, thus causing the federal funds rate to rise to stabilize the economy.

For households, spending decisions on motor vehicles, other durable goods, and housing depend on aggregate consumption as well as real interest rates on consumer loans and home mortgages. Aggregate consumption depends on total wealth, which includes, among other components, the prevailing market value of the outstanding stock of corporate equities. Real interest rates are defined as nominal interest rates on loans for purchases of motor vehicles and other durables and on conventional mortgages, adjusted for the inflation rate expected to prevail over the terms of the corresponding loan. In turn, the values for the consumer loan rate on autos and durables and the mortgage rate are based on the five-year and the ten-year government bond rates, respectively.

For firms in the private business sector, investment decisions depend on a weighted average of borrowing costs in debt and equity markets. The cost of debt finance is proxied by the interest rate on the five-year government bond, adjusted for the expected rate of inflation over a corresponding horizon. The cost of equity finance 
is measured as the expected real return to equity, which is based on the interest rate on the thirty-year government bond, minus the average rate of inflation expected to prevail over a corresponding bond maturity.

Long-term interest rates indirectly affect aggregate demand through the effects of the value of stock market wealth on aggregate consumption and, in particular, by affecting the discount factor applied to the stream of expected future dividends that determine the value of stock market wealth held by households. The market value of the stock of corporate equities held by households, in fact, depends on the present value of dividend payments, with the stream of expected future dividends discounted on the basis of the real interest rate on the thirty-year government bond.

Finally, long-term interest rates also indirectly affect aggregate demand through the effects of the real exchange rate on net exports, by changing the value of the domestic real long-term interest rate that matters for the determination of the real exchange rate. Net exports, in fact, depend on the real exchange rate, which is determined through an interest-parity condition based on the difference between the domestic and the foreign real interest rates on ten-year government bonds.

Another mode of interaction between the SOMA and the FRB/US models occurs through the effects of macroeconomic conditions and the federal funds rate path in the FRB/US model on the evolution of the size and composition of the Federal Reserve's balance sheet in the SOMA model. Across our simulations, in fact, shifts in macroeconomic outcomes affect the size and composition of the balance sheet through the effect of changes in MBS prepayment activity on the path of agency MBS holdings and also through variation in currency growth.

As explained earlier in this appendix, the federal funds rate responds to the output gap and to deviations of inflation from its target. Changes in the paths for the two input variables in the monetary policy rule thus result in shifts in the path for the federal funds rate. Because the ten-year government bond rate depends on a weighted average of the federal funds rates expected over the following forty quarters, shifts in the path for the federal funds rate affect the level as well as the path for the ten-year government bond rate. In turn, the level and the path of the conventional mortgage 
rate are also affected, as this variable is based on the ten-year rate.

This transmission mechanism operating through interest rates is relevant for the interaction between the two models because of the presence of the borrower prepayment option embedded in the mortgages underlying agency MBS. In fact, as the most common motivation for unscheduled mortgage prepayments is rate refinancing, total MBS principal repayments and, thus, the overall path of SOMA MBS holdings hinge importantly on prevailing interest rates, with the refinancing incentive factor in prepayment activity captured by a function of the ratio of the MBS coupon rate to the prevailing mortgage rate.

Moreover, changes in MBS holdings generated by different interest rate paths can in turn result in different paths for SOMA Treasury holdings once the size of the balance sheet is normalized because of the assumption that Treasury securities are also purchased to replace roll-offs of agency MBS as MBS continue to pay down.

Finally, macroeconomic conditions in the FRB/US model affect the evolution of the Federal Reserve's balance sheet in the SOMA model through variation in currency growth. In particular, the assumption that currency expands at a rate equal to that of nominal GDP implies that different paths for nominal GDP growth result in different balance sheet sizes. Because of the assumption that, once the size of the balance sheet is normalized, purchases of Treasury securities resume to keep up with growth in key nonreserve liabilities, different paths for nominal GDP and currency growth necessarily imply different paces of purchases of Treasury securities, thus ultimately affecting holdings of Treasury securities by the Federal Reserve in the longer run.

\section{References}

Adrian, T., R. K. Crump, and E. Moench. 2013. "Pricing the Term Structure with Linear Regressions." Journal of Financial Economics 110 (1): 110-38.

Amador, M., J. Bianchi, L. Bocola, and F. Perri. 2016. "Reverse Speculative Attacks." Journal of Economic Dynamics and Control 72 (November): 125-37. 
Bassetto, M., and T. Messer. 2013. "Fiscal Consequences of Paying Interest on Reserves." Fiscal Studies 34 (4): 413-36.

Bauer, M. D., and G. D. Rudebusch. 2014. "The Signaling Channel for Federal Reserve Bond Purchases." International Journal of Central Banking 10 (3): 233-89.

Benigno, P. 2019. "A Central Bank Theory of Price Level Determination." Forthcoming in American Economic Journal: Macroeconomics.

Benigno, P., and S. Nisticò. 2014. "Monetary Policy Consequences of the Central Bank's Balance Sheet." Technical Report, LUISS Guido Carli.

2019. "Non-Neutrality of Open-Market Operations." Forthcoming in American Economic Journal: Macroeconomics.

Berriel, T. C., and A. Mendes. 2015. "Central Bank Balance Sheet, Liquidity Trap, and Quantitative Easing." Unpublished Manuscript.

Bhattarai, S., G. B. Eggertsson, and B. Gafarov. 2015. "Time Consistency and the Duration of Government Debt: A Signalling Theory of Quantitative Easing." NBER Working Paper No. 21336 (July).

Bonis, B., L. Fiesthumel, and J. Noonan. 2018. "SOMA's Unrealized Loss: What Does It Mean?" FEDS Notes, Board of Governors of the Federal Reserve System (August 13). Available at https://doi.org/10.17016/2380-7172.2234.

Bonis, B., J. Ihrig, and M. Wei. 2017a. "Projected Evolution of the SOMA Portfolio and the 10-Year Treasury Term Premium Effect." FEDS Notes, Board of Governors of the Federal Reserve System (September 22). Available at https://doi.org/10.17016/2380-7172.2081.

. 2017b. "The Effect of the Federal Reserve's Security Holdings on Longer-Term Interest Rates." FEDS Notes, Board of Governors of the Federal Reserve System (April 20). Available at https://doi.org/10.17016/2380-7172.1977.

Bonis, B., J. P. Kandrac, and L. Pardue. 2017. "Principal Payments on the Federal Reserve's Securities Holdings." FEDS Notes, Board of Governors of the Federal Reserve System (June 16). Available at https://doi.org/10.17016/2380-7172.2021.

Brayton, F., T. Laubach, and D. Reifschneider. 2014. "The FRB/US Model: A Tool for Macroeconomic Policy Analysis." 
FEDS Notes, Board of Governors of the Federal Reserve System (April 3). Available at https://www.federalreserve.gov/econres data/notes/feds-notes/2014/a-tool-for-macroeconomicpolicy-analysis.html.

Brayton, F., E. Mauskopf, D. Reifschneider, P. Tinsley, and J. Williams. 1997. "The Role of Expectations in the FRB/US Macroeconomic Model." Federal Reserve Bulletin 83 (4): 227-45. Brayton, F., and P. Tinsley. 1996. "A Guide to FRB/US: A Macroeconomic Model of the United State." Finance and Economics Discussion Series No. 96-42 (October), Board of Governors of the Federal Reserve System.

Bukhari, M., A. Cambron, M. Del Negro, and J. Remache. 2013. "A History of SOMA Income." Liberty Street Economics Blog, Federal Reserve Bank of New York, August 13. Available at http://libertystreeteconomics.newyorkfed.org/2013/08/ahistory-of-soma-income.html.

Bukhari, M., A. Cambron, M. Fleming, J. McCarthy, and J. Remache. 2013. "The SOMA Portfolio through Time." Liberty Street Economics Blog, Federal Reserve Bank of New York, August 12. Available at http://libertystreeteconomics. newyorkfed.org/2013/08/the-soma-portfolio-through-time.html.

Carpenter, S., J. Ihrig, E. Klee, D. Quinn, and A. Boote. 2015. "The Federal Reserve's Balance Sheet and Earnings: A Primer and Projections." International Journal of Central Banking 11 (2): 237-83.

Christensen, J. H. E., J. A. Lopez, and G. D. Rudebusch. 2015. "A Probability-Based Stress Test of Federal Reserve Assets and Income." Journal of Monetary Economics 73 (July): 26-43.

Chung, H., J.-P. Laforte, D. Reifschneider, and J. C. Williams. 2012. "Have We Underestimated the Likelihood and Severity of Zero Lower Bound Events?" Journal of Money, Credit and Banking 44 (s1): 47-82.

Cukierman, A. 2008. "Central Bank Independence and Monetary Policymaking Institutions - Past, Present and Future." European Journal of Political Economy 24 (4): 722-36.

. 2011. "Central Bank Finances and Independence: How Much Capital Should a Central Bank Have?" In The Capital Needs of Central Banks, ed. S. Milton and P. Sinclair, 33-46 (chapter 2). New York: Routledge. 
D'Amico, S., W. English, D. Lopez-Salido, and E. Nelson. 2012. "The Federal Reserve's Large Scale Asset Purchase Programs: Rationale and Effects." Economic Journal 122 (564): 415-46.

Del Negro, M., and C. A. Sims. 2015. "When Does a Central Bank's Balance Sheet Require Fiscal Support?" Journal of Monetary Economics 73 (July): 1-19.

Dziobek, C. H., and J. W. Dalton. 2005. "Central Bank Losses and Experiences in Selected Countries." IMF Working Paper No. 05/72 (April).

Eichengreen, B. 2015. "A Central Bank Needn't Sweat Its Balance Sheet." Japan Times, January 23.

Engen, E. M., T. Laubach, and D. Reifschneider. 2015. "The Macroeconomic Effects of the Federal Reserve's Unconventional Monetary Policies." Finance and Economics Discussion Series No. 2015-005 (January), Board of Governors of the Federal Reserve System. Available at http://dx.doi.org/10.17016/FEDS. 2015.005.

Ferris, E. E. S., S. J. Kim, and B. Schlusche. 2017. "Confidence Interval Projections of the Federal Reserve Balance Sheet and Income." FEDS Notes, Board of Governors of the Federal Reserve System (January 13). Available at https://doi.org/10.17016/2380-7172.1875.

Frame, W. S., A. Fuster, J. Tracy, and J. Vickery. 2015. "The Rescue of Fannie Mae and Freddie Mac." Journal of Economic Perspectives 29 (2): 25-52.

Frame, W. S., and L. J. White. 2005. "Fussing and Fuming over Fannie and Freddie: How Much Smoke, How Much Fire?" Journal of Economic Perspectives 19 (2): 159-84.

Fujiki, H., and H. Tomura. 2017. "Fiscal Cost to Exit Quantitative Easing: The Case of Japan." Japan and the World Economy 42 (June): 1-11.

Gagnon, J., M. Raskin, J. Remache, and B. Sack. 2011. "The Financial Market Effects of the Federal Reserve's Large-Scale Asset Purchases." International Journal of Central Banking 7 (1): 343.

Goncharov, I., V. Ioannidou, and M. Schmalz. 2017. "(Why) Do Central Banks Care about Their Profits?" CESifo Working Paper No. 6546 (June). 
Goodfriend, M. 2014a. "Monetary Policy as a Carry Trade." Monetary and Economic Studies 32 (November): 29-44.

. 2014b. "The Relevance of Federal Reserve Surplus Capital for Current Policy." Economic Policies for the 21st Century (E21), Manhattan Institute, March 17. Available at https:// economics21.org/html/relevance-federal-reserve-surplus-capitalcurrent-policy-77.html and http://shadowfed.org/wp-content/ uploads/2014/03/GoodfriendSOMC-March2014.pdf.

Greenlaw, D., J. D. Hamilton, P. Hooper, and F. S. Mishkin. 2013. "Crunch Time: Fiscal Crises and the Role of Monetary Policy." NBER Working Paper No. 19297 (August).

Greenwood, R., S. G. Hanson, J. S. Rudolph, and L. H. Summers. 2014. "Government Debt Management at the Zero Lower Bound." Working Paper No. 5, Hutchins Center on Fiscal and Monetary Policy (September 30).

Greenwood, R., S. G. Hanson, and J. C. Stein. 2015. "A Comparative-Advantage Approach to Government Debt Maturity." Journal of Finance 70 (4): 1683-1722.

Hall, R. E., and R. Reis. 2015. "Maintaining Central-Bank Solvency under New-Style Central Banking." NBER Working Paper No. 21173 (July).

Ito, T., and F. S. Mishkin. 2006. "Two Decades of Japanese Monetary Policy and the Deflation Problem." In Monetary Policy with Very Low Inflation in the Pacific Rim, Vol. 15, ed. I. Takatoshi and A. K. Rose, 131-202 (chapter 4). Chicago: University of Chicago Press. Available at http://www.nber.org/ chapters/c0092.

Kim, D. H., and J. H. Wright. 2005. "An Arbitrage-Free ThreeFactor Term Structure Model and the Recent Behavior of LongTerm Yields and Distant-Horizon Forward Rates." Finance and Economics Discussion Series No. 2005-33, Board of Governors of the Federal Reserve System (August).

Klüh, U. H., and P. Stella. 2008. "Central Bank Financial Strength and Policy Performance: An Econometric Evaluation." IMF Working Paper No. 08/176 (July).

Kuttner, K. N., and A. S. Posen. 2001. "The Great Recession: Lessons for Macroeconomic Policy from Japan." Brookings Papers on Economic Activity 32 (2, Fall): 93-185. 
Leone, A. M. 1993. "Institutional and Operational Aspects of Central Bank Losses." IMF Papers on Policy Analysis and Assessment No. 93/14 (September).

Li, C., and M. Wei. 2013. "Term Structure Modeling with Supply Factors and the Federal Reserve's Large-Scale Asset Purchase Programs." International Journal of Central Banking 9 (1): 3-39. McLaren, N., and T. Smith. 2013. "The Profile of Cash Transfers between the Asset Purchase Facility and Her Majesty's Treasury." Quarterly Bulletin (Bank of England) Q1 (March). Available at https://ssrn.com/abstract $=2243567$.

Reis, R. 2013. "The Mystique Surrounding the Central Bank's Balance Sheet, Applied to the European Crisis." American Economic Review 103 (3): 135-40.

2016. "Funding Quantitative Easing to Target Inflation." In Designing Resilient Monetary Policy Frameworks for the Future. Proceedings of the Annual Economic Policy Symposium sponsored by the Federal Reserve Bank of Kansas City, held in Jackson Hole, Wyoming, August 25-27.

Richard, S. F., and R. Roll. 1989. "Prepayments on Fixed-Rate Mortgage-Backed Securities." Journal of Portfolio Management 15 (3): 73-82.

Rosengren, E. S. 2013. "Comments on the paper "Crunch Time: Fiscal Crises and the Role of Monetary Policy'." Presented at the U.S. Monetary Policy Forum, New York, February 22. Available at https://www.bostonfed.org/news-and-events/ speeches/comments-on-the-paper-ldquocrunch-time-fiscalcrises-and-the-role-of-monetary-policyrdquo.aspx.

Sims, C. A. 2005. "Limits to Inflation Targeting." In The Inflation-Targeting Debate, Vol. 32, ed. B. S. Bernanke and M. Woodford, 283-310 (chapter 9). NBER Studies in Business Cycles. Chicago: University of Chicago Press. Available at http://www.nber.org/chapters/c9562.

—. 2013. "Paper Money." American Economic Review 103 (2): 563-84.

Stella, P. 1997. "Do Central Banks Need Capital?" IMF Working Paper No. 97/83 (July).

- 2005. "Central Bank Financial Strength, Transparency, and Policy Credibility." IMF Staff Papers 52 (2): 335-65. 
- 2009. "The Federal Reserve System Balance Sheet: What Happened and Why It Matters." IMF Working Paper No. 09/120 (May).

Swanson, E. T. 2011. "Let's Twist Again: A High-Frequency EventStudy Analysis of Operation Twist and Its Implications for QE2." Brookings Papers on Economic Activity 42 (1, Spring): 151-207.

Swiss National Bank. 2015. Quarterly Bulletin 33 (March).

Taylor, J. B. 1999. "A Historical Analysis of Monetary Policy Rules." In Monetary Policy Rules, Vol. 31 of NBER Studies in Business Cycles, ed. J. B. Taylor, 319-48 (chapter 7). Chicago: University of Chicago Press. Available at http://www.nber.org/chapters/c7419.

Wallace, N. 1981. "A Modigliani-Miller Theorem for Open-Market Operations." American Economic Review 71 (3): 267-74. 